\title{
A comparative analysis of VAT grouping schemes from a Nordic perspective-aspects of tax avoidance and fiscal competition*
}

DOI 10.1515/ntaxj-2017-0001

Received Feb 28, 2017; accepted Mar 17, 2017

\begin{abstract}
Value-added tax (VAT) grouping schemes, whereby several legally independent entities are treated as a single taxable person for VAT purposes, are well known, though their detailed rules differ from country to country. This article deals with specific tax avoidance and fiscal competition aspects of VAT grouping schemes in Denmark, Norway, and Sweden. The article gives examples of tax abuse and avoidance by using various VAT grouping models, with the main emphasis on the practice in Denmark, which may be indicative of similar problems in other countries. The article shows that there are significant differences in the rationales for national VAT grouping schemes, and these indicate that there are mismatches between the national schemes of the EU Member States and the original intention of the EU scheme. Finally, an examination of the different national rationales shows the necessity of striking a balance between combating tax avoidance and preventing distortion of competition.
\end{abstract}

Keywords: VAT group, VAT grouping, Nordic countries, Tax avoidance, VAT abuse, Fiscal competition

Karina Kim Egholm Elgaard: Assistant Professor and post-doctoral fellow at the University of Copenhagen, Denmark; Email: karina.egholm.elgaard@jur.ku.dk.

* The article is part of a post-doctoral project, "Combating Tax Avoidance and Protecting the Internal Market-EU VAT Grouping (COMBAT)," which is financed by the Danish Council for Independent Research and the award of the Sapere Aude-Research Talent Prize in 2016 (DFF-6109-00146). Thanks are also due to the FSR Foundation for Educational and Supportive Purposes for financial support for travel expenses and English language revision. Special thanks are due to the Lund University, School of Economics and Management, Sweden; the Norwegian Business School (BI), Department of Law, Norway; and the Stockholm University, Faculty of Law, Sweden, for hosting research visits. Many thanks to Professor Peter Melz of the Stockholm University, Associate Professor Anders Mikelsen of the Norwegian Business School, and Professor Jacob Graff Nielsen, Dean

\section{Introduction and EU Background}

\subsection{Problems with VAT Grouping Schemes}

Value-added tax (VAT) grouping schemes, whereby several legally independent entities are treated as a single taxable person for VAT purposes, are common and well known in the world of VAT/general sales tax (GST). While some of the typical elements of VAT grouping schemes are quite similar in most national VAT grouping schemes (there is one taxable person, internal supplies are outside the scope of VAT, VAT deductions are made on a group basis, only one VAT return is made, etc.) Doesum et al. (2016), the detailed rules and characteristics vary from country to country. It might be expected that in the EU countries, including Denmark and Sweden, VAT grouping schemes implemented in national law ${ }^{1}$ would be harmonized on the basis of the EU VAT Directive, ${ }^{2}$ but this is far from the case Pfeiffer (2015a); Swinkels (2010); Parolini (2009) (see Sections 1.2 and 5). In third countries and non-EU European Economic Area (EEA) countries such as Norway, national rules can be framed independently of the EU rules as their fiscal sovereignty is not bound by membership of the European Union. ${ }^{3}$

Within the European Union and globally, different national VAT grouping schemes can give rise to complex problems relating to tax avoidance and fiscal competition. For example, this can be the case where there is tax competition between states that have VAT grouping schemes and states that do not have VAT grouping schemes or where dif-

of the Faculty of Law at the University of Copenhagen for being excellent sparring partners and providing valuable comments on this article.

1 Currently, 19 EU Member States have implemented rules on VAT grouping or joint registration Soares and Arnaldo (2015).

2 Council Directive 2006/112/EC of November 28, 2006, on the common system of value-added tax (the "VAT Directive").

3 Nevertheless, Norway has close ties to the European Union under the EEA Agreement (see Section 6). 
ferences in national VAT grouping rules on the treatment of cross-border trade to and from VAT groups are exploited in order to obtain double non-taxation. At a national level, competition between sectors on the same market that are favored by having the option of VAT grouping and sectors that are not so favored can be distorted by the use of VAT groups. Further, VAT groups can be used to obtain unintended VAT advantages by abuse and avoidance in connection with VAT exemptions and deductions and so on.

This article focuses on the problems of tax avoidance and fiscal competition from a Nordic perspective, based on a comparative analysis of the VAT grouping schemes in Denmark, Norway, and Sweden and with an emphasis on the contextual and teleological interpretation of the rules on VAT grouping (see Section 2.2). This Nordic perspective on VAT grouping gives just a small part of the global picture that can be used as a basis for a discussion of similar problems internationally.

The results presented in this article are new, as previous research projects have focused more on the subject matter of the rules and less on the aspects of tax avoidance and fiscal competition Pfeiffer (2015a,b); Ehrke-Rabel (2015); Eskildsen (2011); Vyncke (2009); Alhager (2001); Westberg (1994). Of course these aspects have been explored before Swinkels (2005, 2010); Vyncke (2007), but not like in this article.

\subsection{EU VAT Grouping Schemes}

Since 2009, and long before that Swinkels (2010), the EU Commission clearly expressed concerns that differing implementations of the rules on VAT grouping by the EU Member States are highly problematic in terms of VAT fraud and evasion, breach of fiscal neutrality and fiscal competition, potentially affecting the internal market and the basic principles of the EU VAT system. ${ }^{4}$ However, the Court of Justice of the European Union (CJEU) has not agreed with the Commission, and in numerous cases, ${ }^{5}$ it

\footnotetext{
$4 \operatorname{COM}(2009) 325$ final of July 2, 2009, p. 2. The communication is discussed by Massin and Vyncke (2009).

5 Case C-480/10 Commission v Sweden ECLI:EU:C:2013:263; Case C65/11 Commission v Netherlands ECLI:EU:C:2013:265; Case C-74/11 Commission v Finland ECLI:EU:C:2013:266; Case C-85/11 Commission v Ireland ECLI:EU:C:2013:217; Case C-86/11 Commission v United Kingdom ECLI:EU:C:2013:267; Case C-95/11 Commission v Denmark ECLI:EU:C:2013:268; and Case C-109/11 Commission v Czech Republic ECLI:EU:C:2013:269. The majority of the cases are commented by Terra and Kajus (2014).
}

has ruled that differing national implementations are in accordance with the VAT Directive.

Thus the opinion of the Commission remains to be verified or falsified. The purpose of the article is to examine these problems raised by the Commission from a Nordic perspective.

Given the shared EU background to the Danish and Swedish rules on VAT grouping, it might be expected that they would be largely similar, but there are certain differences in their national rationales for the rules and their balancing of the concerns for tax avoidance and fiscal competition (see Section 7). It might also be expected that the Nordic VAT grouping schemes would be quite similar, given the traditionally high degree of exchange of ideas and inspiration on rules and best practice within the Nordic legal community. This article proves otherwise (see Section 2.1 on the reasons for selecting Denmark, Norway, and Sweden as representatives of the Nordic legal community in this article).

\subsection{Margin of Discretion under the VAT Directive}

So far the CJEU has not found that a Member State has exceeded its margin of discretion under Article 11 of the VAT Directive that empowers Member States to introduce VAT grouping schemes (see Section 5). Recently, in the Larentia + Minerva and Marenave case, ${ }^{6}$ the CJEU stated that, within their margin of discretion, the Member States are entitled to make the application of their national VAT grouping schemes subject to certain restrictions, provided those restrictions further the objectives of Article 11 to prevent abusive practices or to combat tax evasion or tax avoidance. ${ }^{7}$ Such restrictions must be necessary and appropriate for attaining these objectives, ${ }^{8}$ that is, they must comply with the proportionality principle.

The margin of discretion under Article 11 of the VAT Directive compliance with the proportionality principle will be taken into account in the analysis of Danish and Swedish law (see Section 8.3).

6 Joined Cases C-108/14 and C-109/14 Larentia + Minerva and Marenave ECLI:EU:C:2015:496. The case is commented by Merkx (2016). 7 Joined Cases C-108/14 and C-109/14 Larentia + Minerva and Marenave, para. 41. Case C-480/10 Commission v Sweden; and Case C-74/11 Commission v Finland.

8 Joined Cases C-108/14 and C-109/14 Larentia + Minerva and Marenave, para. 43 . 


\section{Purpose, Delimitation, and Method}

\subsection{Purpose of the Article and Delimitations}

The purpose of the article is to examine whether the different VAT grouping schemes in the Nordic countries (Denmark, Norway, and Sweden) actually cause problems in terms of tax abuse and avoidance or distortion of competition and to examine how such problems are dealt with by these countries. The concepts of "tax avoidance" and "fiscal competition," as used in this article, are explained in Section 4. An important aim of this article is to examine how these problems interact with the purposes, backgrounds, and national characteristics that lie behind the different national VAT grouping schemes and to see what their consequences may be for the analysis of the national schemes.

These three Nordic countries have been selected because of their geographical proximity, with borders that facilitate considerable cross-border trade and mobility of workers. These countries are also part of a Nordic legal community (see Section 1.2), with shared histories and common traditions, royal ties, cultures, identities and mentalities, and so on. The similarities of their languages also make it logical to choose them for the purposes of this study. The comparative analysis of the selected countries will provide new information as to the understanding and application of the concept of VAT grouping in the European Union Kristoffersson (2016).

The references to national case law and administrative practices in this article are not exhaustive but are the result of subjective assessments of the cases that best fulfill the purposes of the article and most clearly furnish proof of tax avoidance or fiscal competition in practice. Only publicly available cases have been used in this research. It might have been interesting to have had access to unpublished material from the national tax authorities in cases where an application for VAT group registration has been refused or a VAT group has been deregistered by reference to tax avoidance or fiscal competition. Sweden, in particular, would have been interesting in this respect, as it has specific rules to prevent abuse and avoidance (see Section 7.3). A further research project may enable this issue to be studied.

The Skandia America case, ${ }^{9}$ which illustrates the cross-border problems and complications of having dif-

9 Case C-7/13 Skandia America ECLI:EU:C:2014:2225. ferent national VAT grouping schemes in conjunction with the VAT treatment of head office/branch transactions based on the FCE Bank case, ${ }^{10}$ is highly relevant from a Nordic perspective Bjørnholm and Juul (2015); Kristoffersson (2014, 2015); Nedimovic and Tovsen (2014); Norden (2016); Cornielje and Bondarev (2015). However, crossborder issues involving VAT groups will be analyzed from a Nordic perspective in a separate article.

\subsection{Comparative Analysis-Contextual and Teleological Interpretation}

This article applies the method of comparative analysis to the rules on VAT grouping in Denmark, Norway, and Sweden. Comparative analysis can be used to gain new knowledge, insight, understanding, inspiration, and perspectives Elgaard (2016a); Tvarnøe and Nielsen (2014); Kristoffersson $(2010,2016)$.

Given the purposes of this article, the comparative analysis focuses specifically on areas of VAT grouping that relate to tax avoidance and fiscal competition (see Section 2.1). Such broad themes in a comparative analysis can help provide a better understanding of the structure of the issues and possible solutions in national systems Ault (1999).

In the comparative analysis, there is an emphasis on the contextual interpretations of the national rules on VAT groups so as to fully understand the rationales for the national VAT grouping schemes Hellner (1994); Westberg (1994). Contextual interpretation is natural for Denmark and Sweden, as it is an interpretative principle applied by the CJEU ${ }^{11}$ Terra and Kajus (2014), which is the highest authoritative interpreter of the EU law Elgaard (2016a,b). ${ }^{12}$

The comparative analysis emphasizes the teleological interpretation of the national rules on VAT grouping in order to examine the purposes and intentions for the rules. Again, this is natural for Denmark and Sweden, as the CJEU applies teleological interpretations to the EU rules Rendahl (2016). ${ }^{13}$ Teleological interpretation is generally based on the travaux préparatoires, that

10 Case C-210/04 FCE Bank ECLI:EU:C:2006:196. 11 Case 283/81 Cilfit ECLI:EU:C:1982:335; Case C-223/98 Adidas ECLI:EU:C:1999:500; Case C-17/03 Vereniging voor Energie ECLI:EU:C:2005:362; Case C-173/06 Agrover ECLI:EU:C:2007:612; and Case C-583/11 P - Inuit Tapiriit Kanatami ECLI:EU:C:2013:625.

12 Treaty on the Functioning of the European Union (TFEU) Article 267.

13 Case 283/81 Cilfit; Case 292/82 Merck ECLI:EU:C:1983:335; Case C-301/98 KVS ECLI:EU:C:2000:269; Joined Cases C-544/03 and C- 
is, the declared purpose of a measure, comments on proposed legislation, responses from the Minister of Taxation, and so on, which are all relevant for the interpretation of a law Nordquist (2011); Peczenik (1998); Zimmer (2014); Gjems-Onstad (1998).

\section{Structure of the Article}

Given the research purpose of the article set out in Section 2.1 and the methods described in Section 2.2, this article is structured as follows:

First, the basic concepts and definitions used in the article are briefly explained in Section 4. Next, the EU background to the VAT grouping schemes in Denmark and Sweden is thoroughly examined in Section 5 , followed by a brief discussion of Norway's position as an EEA member in Section 6.

In Section 7, the differences and similarities in the rationales for the national VAT grouping schemes in Norway, Denmark, and Sweden are analyzed. Then, in Section 8, the risks of tax avoidance and the distortion of competition in connection with VAT groups are analyzed on the basis of the national case law and administrative practice in these countries. VAT grouping schemes are briefly compared with joint income taxation schemes in Section 9, and the conclusions and considerations are laid out in Section 10.

\section{Basic Concepts and Definitions}

The concepts of "tax avoidance" and "fiscal competition," as used in this article, must be explained briefly, as they are focus points in the comparative analysis (see Section 2.2). The explanations are based on the existing concepts in law and add nothing new.

\subsection{The Concept of "Tax Avoidance"}

The concept of "tax avoidance" is important for the purpose of the article, as one of the research purposes is to examine whether VAT grouping rules in the Nordic countries have been perceived to entail unjustified advantages

545/03 Mobistar and Belgacom Mobile ECLI:EU:C:2005:518; and Case C-298/07 deutsche internet versicherung ECLI:EU:C:2008:572. or room for tax avoidance and how these advantages and avoidance issues have been dealt with (see Section 2.1).

\subsubsection{Tax Avoidance and VAT Abuse in Denmark and Sweden}

In general, the distinction between tax avoidance and tax abuse is not clear Cooper (1997) and the concepts are often used more or less in the same way Piantavigna (2011); Kofler and Tumpel (2009); Monès et al. (2010). A similar approach is used in this article based on a purpose test to define tax avoidance: “... if the primary purpose is to obtain tax benefits and the transaction would not have been carried out in the absence of those benefits, the transaction is unacceptable tax avoidance" Arnold (1997, 228). A variation of the purpose test could be seen whether a behavior is contrary to the purpose of the rule: “...tax avoidance arises in connection with the exploitation of the friction between form and substance aimed at circumventing the scope of a tax provision” Pistone and Szudoczky $(2016,46)$. As seen in the following text, such purpose tests on tax avoidance is to a large extent reflected in the concept of VAT abuse-at least for the purposes of this article (see Sections 2.1 and 4.1)-thus avoidance and abuse are used more or less in the same way in the article.

Differences in national rules preventing abuse and avoidance must be taken into account, as they have an impact on the comparative analysis of VAT grouping schemes. One obvious difference is that Denmark and Sweden are subject to the VAT Directive and the CJEU's case law, whereas Norway is generally only subject to Norwegian VAT regulations and case law (see Section 4.1.2).

Since the Halifax case, ${ }^{14}$ the anti-abuse doctrine developed in the EU VAT case law has been part of national VAT law in the Member States in the opinion of many academics Feria (2011); Swinkels (2011); Kristoffersson $(2013 a, b)$. However, some academics are of another opinion Jensen $(2011,2015)$, but this discussion is outside the scope of this article. Under the VAT anti-abuse doctrine, a transaction can constitute VAT abuse if it results in the gaining of a tax advantage that would be contrary to the purpose of the relevant provisions and if it is objectively clear that the essential aim of the transaction is to

14 Case C-255/02 Halifax ECLI:EU:C:2006:121. See also Case C-425/06, Part Service ECLI:EU:C:2008:108; Case C-277/09, RBS Deutschland ECLI:EU:C:2010:810; Case C-33/11, A Oy ECLI:EU:C:2012:482; and Case C-272/13, Equoland ECLI:EU:C:2014:2091. 
obtain a tax advantage. ${ }^{15}$ If a transaction may have some other aim than the mere attainment of a tax advantage, the VAT anti-abuse doctrine is not relevant. ${ }^{16}$

The term "VAT abuse," as used in this article, refers explicitly to the EU VAT anti-abuse doctrine and national implementations of it.

Before the VAT anti-abuse doctrine was clarified in the Halifax case, the CJEU had established that consideration for financial and commercial realities is a fundamental criterion for the application of the EU VAT system. ${ }^{17}$ Consequently, a transaction can be disregarded for VAT purposes if it is not consistent with the financial and commercial reality. This is another legal means for combating abusive practices or conduct besides the VAT anti-abuse doctrine Jensen (2011, 2014).

Denmark and Sweden may have national VAT rules on anti-avoidance in addition to those rules developed in the EU case law, but it is outside the scope of this article to consider such rules in greater detail (see Section 2.1).

\subsubsection{Norwegian Anti-Avoidance Concept of Gjennomskæring}

Norway has developed its own national case law based on the concept of gjennomskæring. ${ }^{18}$ Gjennomskæring refers to "anti-avoidance" whereby an abusive practice or conduct can be disregarded for tax purposes Gjems-Onstad (2009). In Norwegian legal doctrine, anti-avoidance is distinguished from purely pro forma situations and the strict or restrictive/wide or expansive interpretation of a rule. Naturally, pro forma situations are disregarded for tax purposes because substance is different from form. In distinguishing between anti-avoidance and a restrictive/expansive interpretation of the law, it is more difficult to draw a line and characterize transactions as un-

15 Case C-255/02 Halifax, paras. 74-75.

16 Case C-255/02 Halifax, para. 75.

17 Case C-260/95 DFDS ECLI:EU:C:1997:77; Case C-185/01 Auto Lease Holland ECLI:EU:C:2003:73; Case C-73/06 Planzer Luxembourg ECLI:EU:C:2007:397; Joined Cases C-53/09 and C-55/09 Loyalty Management and Baxi Group ECLI:EU:C:2010:590; and Case C-653/11 Newey ECLI:EU:C:2013:409.

18 The literal English translation is "cutting through." Same linguistic usage is found in Odelstingsproposisjon [Ot.prp.] No 16 (1991/92) Oppfølgning av skattereformen 1992 [Government Bill] (Nor.); Sivilombudsmannen's [Parliamentary Ombudsman for Public Administration] letter of August 17, 1994 to Skattedirektoratet [SKD] [Directorate of Taxes] (Nor.) Killengreen et al. (2000a,b). acceptable Gjems-Onstad and Kildal (2013); Gjems-Onstad (2009); Løvaas (2007); Killengreen et al. (2000a).

From an outsider's perspective, based on the principle of legal certainty and the requirement for legal justification, the term "anti-avoidance" should be reserved for situations where an abusive practice or conduct can be clearly established, and a restrictive/expansive interpretation of the law should be distinguished from such abusive situations Gjems-Onstad (2009); Fjermeros (2014). However, it is likely that a suspicion or indications of abuse in a case may influence the interpretation of law toward a more restrictive/expansive interpretation and, in conjunction with other elements upon which the decision is made, such suspicion or indications may affect a decision even if there is no direct reference to abuse. However, this distinction is not important here because both situations would be interesting for the research purpose (see Section 4.1).

The application to VAT law of the anti-avoidance concept derived from case law has been discussed in Norway, but from the case law of the Norwegian Supreme Court, ${ }^{19}$ it must be concluded that the tax law anti-avoidance concept is also generally applicable to VAT law GjemsOnstad (2016); Gjems-Onstad and Kildal (2013); Fjermeros (2014), including to VAT groups Gjems-Onstad et al. (2016); Bråthen et al. (2012).

The concept means that anti-avoidance cannot be established purely because a transaction is motivated by obtaining a tax advantage, but anti-avoidance can be established if obtaining a tax advantage is the main purpose of a transaction. This must be based on an overall evaluation in which the key questions are what value (egenverdi) a transaction has other than tax saving and whether the taxable result of a transaction is contrary to the purpose of the rule. ${ }^{20}$ Another determining factor is whether a trans-

19 Høyesteret [HR] [Supreme Court] 2006-10-13, Rt. 2006 p. 1199 Nagell-Erichsen (Nor.); Høyesteret [HR] Supreme Court] 2011-02-16, Rt. 2011 p. 213 Invex (Nor.); and Høyesteret [HR] [Supreme Court] 201205-24, Rt. 2012 p. 840 Grasmo (Nor.). The Invex case is commented by Larsen (2011).

20 Høyesteret [HR] [Supreme Court] 1999-06-28, Rt. 1999 p. 955 ABB (Nor.); Høyesteret [HR] [Supreme Court] 2002-04-29, Rt. 2002 p. 456 Hydro (Nor.); Høyesteret [HR] [Supreme Court] 2007-02-13, Rt. 2007 p. 209 Hex (Nor.); Høyesteret [HR] [Supreme Court] 2004-09-08, Rt. 2004 p. 1331 Aker (Nor.); Høyesteret [HR] [Supreme Court] 2006-09-07, Rt. 2006 p. 1062 Fauske (Nor.); Høyesteret [HR] [Supreme Court] 2006-1017, Rt. 2006 p. 1232 Telenor (Nor.); Høyesteret [HR] [Supreme Court] 2008-11-12, Rt. 2008 p. 1510 Reitan (Nor.); Høyesteret [HR] [Supreme Court] 2008-11-13, Rt. 2008 p. 1537 ConocoPhillips (Nor.); Høyesteret [HR] [Supreme Court] 2012-12-17, Rt. 2012 p. 1888 Dyvi (Nor.); and Høyesteret [HR] [Supreme Court] 2014-03-12, Rt. 2014 p. 227 Tangen (Nor.). The Reitan case is commented by Lundeland (2009) and the 
action is intended to take disloyal advantage of the rules. 21

The Zimmer committee proposed introducing a general anti-avoidance clause to be applied to both direct and indirect taxation, but it is not yet adopted. ${ }^{22}$

It is outside the scope of this article to elaborate further on the concept of tax avoidance, but the national differences will be taken into account in the analysis of the Nordic VAT grouping schemes.

\subsection{Definition of "Fiscal Competition"}

The term "fiscal competition" used in the article is given the broadest possible meaning. "Fiscal competition" covers all potential aspects of fiscal competition that are relevant to the research purpose of this article (see Section 2.1). The examples of fiscal competition given in the following are, therefore, not exhaustive.

\subsubsection{Tax Competition between States}

Fiscal or tax competition generally refers to the situation where different states compete against each other by offering favorable national tax rules to maximize the state's tax revenue by attracting foreign resources and investments Andersson and Fall (2001); Ault (2002); Schön (2002). There are both positive and negative effects of fiscal competition Lampreave (2011); Cerioni (2005) but normally harmful competition and distortion of competition are considered to have negative effects and should be removed, especially in the EU regime Vanistendael (2001).

The removal of distortions of competition and hindrances to the free movement of goods and services within the European Union has been part of the establishment of the internal market in which the harmonization of the EU VAT system has played a part. ${ }^{23}$ Other EU remedies for combating distortions of competition include the Treaty-

Telenor, Nagell-Erichsen, and Fauske cases are commented by Zimmer (2007).

21 Rt. 2002 p. 456 Hydro; Rt. 2004 p. 1331 Aker (Nor.); Rt. 2011 p. 213 Invex (Nor.); and Rt. 2014 p. 227 Tangen (Nor.). The Tangen case is commented by Folkvord (2015).

22 Noregs offentlege utgreiingar [NOU] 2016:5 Omgåelsesregel i skatteretten - Lovfesting av en generell omgåelsesregel i skatteretten [government report] (Nor.). The report has been criticised by Folkvord (2016); Gjems-Onstad (2016); Mikelsen (2016).

23 TFEU Article 113 and Preamble 1-4 of the VAT Directive. COM(2016) 148 final of 7 April 2016. based principle of equal treatment Ridsdale (2005) ${ }^{24}$; this is reflected in the VAT neutrality principle ${ }^{25}$ but is not the same Amand (2013); Soares and Arnaldo (2015); Doesum et al. (2016). ${ }^{26}$ While the VAT neutrality principle is the most important fundamental principle in the EU VAT system Elgaard (2016a); Papis (2014); Alhager (2001), the principle in itself is not directly relevant to the concrete purpose of the article, which uses a broader and more general definition of fiscal competition (see Section 4.2). Furthermore, the aspects of tax competition between states and the EU aspects of fiscal competition are not directly relevant for the article, as cross-border situations involving VAT groups are outside its scope (see Section 2.1), but these aspects are addressed, if relevant.

\subsubsection{Fiscal Competition at National Level}

There are other aspects of fiscal competition or competition neutrality that affect businesses and customers at national level.

Where businesses compete on the same market, there may be fiscal competition if one business has a tax advantage and thereby achieves a better competitive position than other businesses operating on the same market. In that case, the tax advantage distorts competition Vanistendael (2001). An example of trying to avoid such distortion of competition is the VAT exemption for independent groups of persons who carry on an activity that is exempt from VAT or in relation to which they are not taxable persons pursuant to Article 132(1)(f) of the VAT Directive. One of the conditions for allowing the VAT exemption is exactly that it must not be likely to distort competition. ${ }^{27}$

In relation to customers, there may be fiscal competition where a customer would choose one product over another because the chosen product is cheaper, because of a tax advantage granted in the supply chain prior to the sale to the end customer. For example, a tax advantage may be obtained by allowing a VAT exemption to independent groups or a VAT group.

24 TFEU Article 19.

25 Preamble 5, 7, and 30 of the VAT Directive. Case C-216/97 Gregg ECLI:EU:C:1999:390; Joint Cases C-443/04 and C-444/04 Solleveld ECLI:EU:C:2006:257; Case C-309/06 Marks \& Spencer ECLI:EU:C:2008:211; Case C-174/08 NCC Construction Danmark ECLI:EU:C:2009:669; and Case C-440/12 Metropol Spielstätten ECLI:EU:C:2013:687.

26 Case C-309/06 Marks \& Spencer; and Case C-480/10 Commission v Sweden.

27 Case C-8/01 Taksatorringen ECLI:EU:C:2003:621. 
The broad and general definition of fiscal competition used in this article relates primarily to the fiscal competition or competition neutrality affecting businesses and customers at national level.

\section{The EU Harmonized Background in Denmark and Sweden}

Denmark and Sweden share the same EU background. Their national implementations of the EU rules on VAT grouping are based on Article 11 of the VAT Directive:

\begin{abstract}
"After consulting the advisory committee on value added tax (hereafter, the 'VAT Committee'), each Member State may regard as a single taxable person any persons established in the territory of that Member State who, while legally independent, are closely bound to one another by financial, economic and organisational links.

A Member State exercising the option provided for in the first paragraph, may adopt any measures needed to prevent tax evasion through the use of this provision."
\end{abstract}

It appears from the provision that it is optional for the Member States to implement rules on VAT grouping and to implement measures against tax evasion (see Section 5.3). The provision is very broad, laying down few conditions. It allows the Member States to design their own national VAT grouping schemes, largely at their discretion. The reason for the differing national implementations of the EU VAT grouping schemes (see Section 1.2) is implicit in the minimalistic formulation of Article 11 of the VAT Directive.

\subsection{Article 4 of the Sixth VAT Directive}

The wording of Article 11, first paragraph, of the VAT Directive is very similar to that of Article 4(4), second paragraph, of the Sixth VAT Directive. ${ }^{28}$ The purpose of the provision was given in the proposal for the Sixth VAT Directive: ${ }^{29}$

"Moreover, paragraph 4 goes into finer details, so that, in the interests of simplifying administration or of combating abuses

28 Sixth Council Directive of 17 May 1977 (77/388/EEC) (the "Sixth VAT Directive"). The provision originates from the Second VAT Directive of April 11, 1967 (67/228/EEC) (the "Second VAT Directive") Article 4, Annex A, para. 2 Pfeiffer (2015a); Vyncke (2009); Terra and Kajus (2014), and COM(65) 144 final of April 13, 1965, Article 2, Annex A, para. 2.

$29 \operatorname{COM}(73) 950$ final of June 20, 1973. (e.g. the splitting up of one undertaking among several taxable persons so that each may benefit from a special scheme) Member States will not be obliged to treat as taxable persons those whose 'independence' is purely a legal technicality."

Thus, the purpose of VAT grouping schemes based on the Sixth VAT Directive was to simplify administration or combat abuse, for example, where advantage is taken of different VAT schemes and when such advantage arises purely from legal technicalities as to the definition of "independence." The objective of simplifying administration is not specified in the proposal, but the Commission has subsequently stated that VAT grouping schemes should predominantly be seen as a simplifying measures. ${ }^{30}$

The purpose of combating abuse is described in more detail. It is stated that the aim of VAT grouping schemes was to combat purely technical-legal arrangements where the independence of separate taxable persons does not conform to reality. A literal interpretation could be that the purpose was to authorize Member States to disregard, for VAT purposes, artificial arrangements of several taxable persons when in reality such persons should be considered as one taxable person for VAT purposes. ${ }^{31}$ Thus VAT grouping schemes seem to be intended to enable the Member States to combat artificial arrangements Millar et al. (2016); Soares and Arnaldo (2015) - and not an option for taxable persons to use for their benefit Swinkels (2010). Only a few Member States have implemented mandatory VAT grouping schemes. Neither Denmark nor Sweden has mandatory VAT grouping schemes. A less literal interpretation could be that VAT grouping schemes could be used by the Member States to combat abuse in connection with legal technicalities, artificial arrangements, or so forth. This does not prevent VAT grouping schemes being used for other purposes. This is the legal and practical reality today, as exemplified by Denmark and Sweden (see Sections 7.2 and 7.3).

$30 \operatorname{COM}(2009) 325$ final of July 2, 2009, p. 12. Joep Swinkels has questioned the actuality of the simplification purpose from a contemporary view Swinkels (2010).

31 As described by the Commission of the European Communities in $\operatorname{COM}(2009) 325$ final, p. 4: "In this regard, a VAT group could be described as a 'fiction' created for VAT purposes, where economic substance is given precedence over legal form." 


\subsection{Amendment of Article 4 of the Sixth VAT Directive}

The purpose of combating abuse is further addressed in the 2006 proposal to amend ${ }^{32}$ Article 4 of the Sixth VAT Directive by the insertion of Article 4(4)(3): ${ }^{33}$

"Although not arising from existing derogations, in Article 1(1) and 1(2) the Commission is taking the opportunity to propose changes to strengthen areas which Member States find can be exploited to avoid VAT. In both the area of 'grouping' in Article 4(4) of the Sixth Directive and in 'transfers of going concerns' (Article 5(9)) the proposal allows for Member States to take steps to ensure that the operation of the rules does not allow an unfair result which would unjustifiably benefit or prejudice those concerned. Member States already have the discretion to set the circumstances in which the both of these rules can apply. The new rule, already applied to capital goods through Article 20(6), would help Member States prevent unfair results arising from the operation of the rules."

Without referring to any example, the EU Commission proposed to amend the rules on VAT grouping in order to strengthen regulations in areas in which the Member States found that there was a risk of VAT avoidance. It was stated that the rules on VAT grouping should not allow an unfair result that would unjustifiably benefit or prejudice those concerned. It is unclear whether "unfair results" and "unjustifiable benefits" only refer to tax avoidance or may also refer to competition neutrality, given the reference to the "prejudice of those concerned," which could imply harmful competition to the prejudice of taxable persons other than those in the VAT group. This is supported by the proposed amended wording of Article 4(4), third paragraph, of the Sixth VAT Directive, which refers to "unjustified disadvantage for taxable persons": ${ }^{34}$

"Where a Member State exercises the option provided for in the second subparagraph, it shall ensure that the application of this option creates neither unjustifiable benefit nor unjustified disadvantage for taxable persons.”

Regardless of any uncertainty about the purpose of the proposal, it must be concluded that the purpose of the 2006 amendment was to deal with tax avoidance, ${ }^{35}$ be-

32 Council Directive 2006/69/EC of July 24, 2006. The overall purpose with the directive was to provide the Member States with the option of quickly adopting legally sound measures in order to counter avoidance and evasion in certain specific and targeted areas, $\operatorname{COM}(2005) 89$ final of March 16, 2005.

$33 \operatorname{COM}(2005) 89$ final of March 16, 2005.

$34 \operatorname{COM}(2005) 89$ final of March 16, 2005.

$35 \operatorname{COM}(2009) 325$ final of July 2, 2009, p. 3. cause the final wording of the amendment to Article 4(4), third paragraph, of the Sixth VAT Directive was the following: ${ }^{36}$

"A Member State exercising the option provided for in the second subparagraph, may adopt any measures needed to prevent tax evasion or avoidance through the use of this provision."

According to this amendment, the Member States are authorized to implement any measures in national law to prevent tax evasion or avoidance in connection with their national VAT grouping schemes. Such measures must be in accordance with the margin of discretion and principle of proportionality pursuant to the current Article 11 of the VAT Directive (see Section 1.3). Thus, for other purposes, for example, if the rules create unjustifiable benefits or disadvantages for taxable persons, the starting point must be outside the scope of Article 11 of the VAT Directive unless these are integral elements of evaluation of tax evasion or avoidance. This is substantiated by the CJEU, which has never referred to purposes other than tax evasion or avoidance in this respect (see Section 1.3 and the cases cited there).

\subsection{Implementation of Special Rules to prevent Abuse and Avoidance}

Sweden has implemented special rules to prevent abuse and avoidance for VAT groups pursuant to Article 11, second paragraph, of the VAT Directive (see Section 7.3). Denmark has not implemented such rules (see Section 7.2). The question is whether the Member States are obliged to implement special anti-avoidance rules for VAT groups even though the provision states that the Member States "may" adopt any measures to combat tax evasion or avoidance (see Section 5). In the author's opinion, the Member States do have such an obligation based on the travaux préparatoires to Article 11, second paragraph, on the general obligation to counter VAT fraud and abuse pursuant to Article 325 of the Treaty on the Functioning of the European Union, Article 2, Article 250(1), and Article 273 of the VAT Directive in combination with Article 4(3) of the Treaty on the European Union and the case law of the CJEU. ${ }^{37}$ It is noted that the EU Commission has not directly called it an

\footnotetext{
36 Council Directive 2006/69/EC of July 24, 2006.

37 Case C-132/06 Commission v Italy ECLI:EU:C:2008:412; Case C367/09 SGS Belgium ECLI:EU:C2010:648; Case C-539/09 Commission v Germany ECLI:EU:C:2011:733; Case C-617/10 Åkerberg Fransson ECLI:EU:C:2013:105; and Case C-105/14 Taricco ECLI:EU:C:2015:555.
} 
"obligation," but the Commission has urged the Member States to make effective use of their powers under Article 11, second paragraph, of the VAT Directive. ${ }^{38}$

\subsection{Article 11, second paragraph, of the VAT Directive}

The final wording of Article 4(4), third paragraph, of the Sixth VAT Directive directly corresponds to Article 11, second paragraph, of the VAT Directive, except that the word "avoidance" is omitted from Article 11 of the VAT Directive. The reason for this is unknown, but avoidance must be covered by Article 11 of the VAT Directive, as it is a recast of the structure and wording of the Sixth VAT Directive, making no substantive amendment to the existing legislation. ${ }^{39}$ Clearly, the CJEU includes both tax evasion and avoidance within the margin of discretion under Article 11 of the VAT Directive $^{40}$ (see Section 1.3).

\subsection{Article 2 of the Second VAT Directive}

Some aspects of fiscal competition have been addressed in the EU rules on VAT groups, but not to the same extent as with the aspects of tax avoidance (see above). This should not be understood as ranking the importance of the two, as it could equally well be seen as expressing a different need for clarification in the travaux préparatoires to the rules. The EU Commission directly addressed issues of fiscal competition in the explanatory comments on the proposal for Article 2 of the Second VAT Directive. ${ }^{41}$ Here the Commission stated that a VAT grouping scheme that allows a German Organschaft to be treated as a single legal person Pfeiffer (2015a,b); Swinkels (2010); Doesum et al. (2016) ${ }^{42}$ in an undiluted application of the VAT system would have no competitive advantage over an Organschaft whose members are treated as separate taxpayers.

$38 \operatorname{COM}(2009) 325$ final of July 2, 2009, p. 12.

39 Preamble 1 and 3 of the VAT Directive. See Case C-29/08 AB SKF ECLI:EU:C:2009:665; Joined Cases C-621/10 and C-129/11 Balkan and Sea Properties and Provadinvest ECLI:EU:C:2012:248; and Case C563/12 BDV Hungary Trading ECLI:EU:C:2013:854. COM(2009) $325 \mathrm{final}$ of July 2, 2009, p. 3.

40 Joined Cases C-108/14 and C-109/14 Larentia + Minerva and Marenave.

$41 \operatorname{COM}(65) 144$ final of April 13, 1965, Explanatory memorandum, III. Explanatory comments on certain provisions of the proposed TVA system, p. 20.

42 Joined cases C-181-229/78 Ketelhandel P. van Paassen BV and Denkavit Dienstbetoon BV ECLI:EU:C:1979:151.
Thus the Commission found that there did not seem to be any major disadvantage if Member States treated an Organschaft as a single taxpayer or as separate taxpayers. However, in 2009, the Commission modified its original view (see Section 1.2).

The national rationales for the Danish and Swedish VAT grouping schemes (see Sections 7.2 and 7.3) must be seen in light of the purpose and background for the EU rules on VAT groups, based on Article 11 of the VAT Directive. In Sections 7.2 and 7.3, it will be seen that the purposes and backgrounds for the Danish and Swedish VAT grouping rules differ significantly from the rationale for the EU rules.

\section{Norway's Relationship to the EU and the VAT Directive}

Norway is not a Member of the European Union, but it is a member of the EEA. ${ }^{43}$ As taxation, including VAT, is not covered by the EEA Agreement Bråthen et al. (2012); Kildal (2008a,b), Norway has almost autonomous powers in the area of tax law, with due respect to the EEA Agreement. Subject to some exceptions, in the area of tax law, the EU legislation and CJEU case law are of no legal consequence to Norway (see below).

There can be exceptions, for example, when national legislation gives the European Union influence over Norwegian VAT law. This is the case in limited areas of VAT law, such as the VAT exemption for financial services, 44 where it is directly stated in the proposal for the rules 45 that Article 13 (B)(a) and (d)(1)-(6) of the Sixth VAT Directive and the EU case law related thereto ${ }^{46}$ will be relevant

43 EØS-loven [EEA Act] (Lov-2014-04-11-11) (Nor.).

44 Merverdiavgiftsloven [MVA-loven] [VAT Act] § 3-6. (LOV-2009-0619-58) (Nor.). The VAT exemption was introduced by Lov om endringer i lov 19. juni $1969 \mathrm{nr} .66$ om merverdiavgift [Endring til MVA-loven] [Amendment to VAT Act] § 5 b. (LOV-2000-12-21-113) (Nor.).

45 Lov om Merverdiavgift [VAT Act] § 5b, first part, No 4 (LOV-196906-19-66) (Nor.); Odelstingsproposisjon [Ot.prp.] Ot.prp. No 2 (20002001) Om lov om endringer i lov 19. juni 1969 nr. 66 om merverdiavgift [government bill] (Nor.); Instillinga til Odeltinget [Innst.O.] Innst.O. No 24 (2000-2001) Om lov om endringer i lov 19. juni 1969 nr. 66 om merverdiavgift (merverdiavgiftsloven) m.v. (Merverdiavgiftsreformen 2001) [government recommendation] (Nor.); and Finansdepartementets tolkingsuttalelse [UFIN] UFIN-2001-10001 Om merverdiavgiftsunntaket for omsetning av finansielle tjenester [Statement from the Department of Finance] (Nor.).

46 In UFIN-2001-10001 (Nor.) reference was made to Case C-349/96 CPP ECLI:EU:C:1999:93; and in Skattedirektoratet's [Directorate of 
for interpreting the national VAT exemption for financial services and, in particular, the definitions used in Sweden and Denmark.

In several cases, the Norwegian Supreme Court has emphasized the relevance of the EU legislation and case law in national matters and has actively used the EU law for interpreting national rules, ${ }^{47}$ while in other cases, it has declined to accept the EU law as being relevant for national law. ${ }^{48}$

In principle, the EU law is not generally relevant for Norwegian law. However, in specific cases where Norwegian legislation states that the rules are harmonized with the EU law or that the rules should be interpreted in accordance with the EU law, the EU law will be relevant, as in the case of the VAT exemption for financial services Dyrnes (2015b); Olsen and Saxegaard (2009); Wroldsen (2014). See also Norli (2016); Ihlebæk (2011). It is then for the Norwegian courts and tax authorities to decide whether the EU law has an impact on a national rule in the specific case.

In the case of VAT grouping, there is no direct link between the EU law and the Norwegian rules, travaux préparatoires, case law, or administrative practice. Thus, the EU law is not generally relevant to the interpretation of the Norwegian VAT grouping rules. Some Norwegian authors argue that the EU law should be relevant to the Norwegian rules on cross-border VAT groups and the crossborder provision of services Norli (2016); Nedimovic and Tovsen (2014), but this is not discussed in this article (see Section 2.1).

\section{Rationales for the National VAT Grouping Schemes}

As the rationale for the EU VAT grouping scheme (see Section 5) is directly relevant for Denmark and Sweden, there is an analysis of the national rationales for the Nordic VAT grouping schemes. The analysis demonstrates that the national rationales differ significantly from each other,

\footnotetext{
Taxes] letter of November 21, 2001, to fylkesskattekontorene (Nor.) reference was made to Case C-2/95 SDC ECLI:EU:C:1997:278.

47 Høyesteret [HR] [Supreme Court] 2007-02-05, Rt. 2007 p. 140 Olympia Capital (Nor.); Høyesteret [HR] [Supreme Court] 2007-1010, Rt. 2007 p. 1401 Norsk Helikopter (Nor.); and Høyesteret [HR] [Supreme Court] 2009-12-22, Rt. 2009 p. 1632 Carnegie/ABG (Nor.). 48 Høyesteret [HR] [Supreme Court] 2006-03-27, Rt. 2006 p. 364 Ifi Oy (Nor.); Høyesteret [HR] [Supreme Court] 2011-02-16, Rt. 2011 p. 213 Invex (Nor.); and Høyesteret [HR] [Supreme Court] 2012-10-11, Rt. 2012 p. 1547 Norwegian Claims Link (Nor.).
}

particularly on tax avoidance and fiscal competition. The analysis looks first at Norway, then at Denmark, and finally, at Sweden. This order is based on the volume of national regulations on VAT groups in each country, starting with the jurisdiction with the fewest provisions through to the jurisdiction with the most provisions.

\subsection{Norwegian Rules on VAT Grouping}

Norway's rules on VAT groups are purely national (see Section 6). The Norwegian VAT grouping scheme was introduced in 1969 at the time of the adoption of the former Norwegian VAT Act. ${ }^{49}$ The proposal for the rules on VAT groups stated that their purpose was twofold, in both granting rights to make VAT deductions and preventing abuse. ${ }^{50}$ The proposal elaborated on the right to make deductions:

\begin{abstract}
"There could be a need to consider several cooperating companies' businesses as a single taxable business. Without such a rule it would not be possible to grant deductions for input VAT on the total business when operating equipment is owned by one company while sales are made by another company." 51
\end{abstract}

Thus, the main purpose of the VAT grouping scheme was to secure an effective right for cooperating companies to deduct input VAT Gjems-Onstad et al. (2016); GjemsOnstad and Kildal (2013). The fiscal competition aspects of the organization of businesses were given high priority by ensuring a right to make a full deduction for the VAT group as a whole, for example, where the companies of a VAT group perform different functions and have different business purposes such as operating or holding companies and sales companies Dyrnes (2015a); Wiig (2014). Commercial and organizational considerations were the main reasons underlying the Norwegian VAT grouping scheme (see Section 8.2 on the criteria for cooperating companies).

The competition neutrality aspect is addressed by Gisla Bråthen, Erik Frøystad, and Ole Martin Haugan, who state that the purpose of the VAT grouping scheme is to achieve neutrality, irrespective of the organization of a business as a single company or a VAT group consisting of several companies. ${ }^{52}$ Commercial reasons, not VAT

49 Lov om merverdiavgift [VAT Act] § 12. (LOV-1969-06-19-66) (Nor.). 50 Odelstingsproposisjon [Ot.prp.] Ot.prp. No 17 (1968-1969) Om lov om alminnelig omsetningsavgift og særskilt avgift på visse varer og tjenester (merverdiavgiftsloven) [government bill] (Nor.).

51 The author's translation.

52 Oslo tingrett [TOSLO] [Oslo District Court] 2011-02-11, TOSLO-2010131949 Nopco (Nor.); Skattedirektoratet's [Directorate of Taxes] col- 
reasons, should determine how a business is organized. These authors see the criteria on cooperating companies (see Section 8.2) as reflecting the objective of organizational neutrality Bråthen et al. (2012).

The focus on fiscal competition can also be seen in Norwegian case law, where a broad interpretation is applied to determining which companies are entitled to form a VAT group. This is because allowing some business entities to form VAT groups but not others could distort competition and conflict with the general principle of equal treatment Gjems-Onstad et al. (2016); Bråthen et al. (2012); Skogrand (2007). ${ }^{53}$

The proposal for the rules on VAT grouping may also refer to the aspect of tax avoidance ${ }^{54}$ : "To prevent abuse of the right of deduction, joint and several liability for VAT payment is required." 55

Given the right of VAT groups to make deductions for the whole VAT group, joint and several liability for VAT was necessary. ${ }^{56}$ This could be seen as a rule to prevent tax avoidance. In fact, the proposal contains a specific rule in order to prevent abuse ${ }^{57}$ : "Considering the liability and in order to prevent abuse, the rule should only apply when at least $85 \%$ of the equity in each company is owned by the same owners." 58

This anti-abuse rule was adopted as part of the rules on VAT grouping (see below). The $85 \%$ rule has been criticized in Norwegian legal literature because of the alleged lack of a legal reason for the exact percentage rule Gjems-Onstad et al. (2016); Gjems-Onstad and Kildal (2013); Dyrnes (2015a). A similar criticism has been made in Denmark about the 100\% rule; such criticism has been linked to other arguments such as its conflict with EU rules and the proportionality principle (see Section 7.2). Norwegian practice shows that the $85 \%$ rule may increase the risks of tax avoidance; this will be discussed in Section 8.2.

The original proposal for the rules on VAT groups was fully implemented in Section 12 of the former Norwegian VAT Act, ${ }^{59}$ which has been carried forward with almost

lective letter of June 16, 2014 [USKD-2014-31] (Nor.); and Finansdepartementets uttalelse [UFIN] UFIN-2007-4A Om Merverdiavgift og fellesregistrering [Statement from the Department of Finance] (Nor.). 53 UFIN-2007-4A (Nor.).

54 Ot.prp. No 17 (1968-1969) (Nor.).

55 The author's translation.

56 Høyesteret [HR] [Supreme Court] 2013-06-12, Rt. 2013 p. $858 \mathrm{Te}$ lenor Eiendom (Nor.).

57 Ot.prp. No 17 (1968-1969) (Nor.).

58 The author's translation.

59 Odelstingsproposisjon [Ot.prp.] Ot.prp. nr. 76 (2008-2009) Om lov om merverdiavgift (merverdiavgiftsloven) [government bill] (Nor.). identical wording in the Section 2-2 (3) of the current Norwegian VAT Act. ${ }^{60}$ Thus, the originally stated rationale for the VAT grouping scheme is still valid. Section 2-2 (3) of the current Norwegian VAT Act states: ${ }^{61}$

\begin{abstract}
"Two or more cooperating companies may be registered as one taxable person if at least $85 \%$ of the capital of each company is owned by one or more of the cooperating companies. All companies that participate in a joint registration shall be jointly liable for the payment of VAT."
\end{abstract}

The Norwegian rules on VAT grouping are short and effective, containing rules on the prevention of distortion of competition and on anti-avoidance. The underlying rationale for the rules is thereby directly reflected in the rules.

According to the travaux préparatoires to the Norwegian rules, the main concerns related more to fiscal competition than tax avoidance. The concerns and rationale for the Danish VAT grouping scheme are quite distinct from those of Norway; see the following section.

\subsection{Danish Rules on VAT Grouping}

The Danish VAT grouping scheme (similar to the Swedish VAT grouping scheme; see Sections 5 and 7.3) is based on implementing Article 11 of the VAT Directive (see Section 5). The current rules on VAT grouping are divided into three provisions in the Danish VAT Act ${ }^{62}$; these are Section 3(3), Section 46(9), and Section 47(4). Section 3(3) is the general rule whereby persons who are registered together pursuant to Section 47(4) of the Danish VAT Act are treated as a single taxable person. Section 46(9) states that several entities that do not have the same owner and are registered together pursuant to Section 47(4) of the VAT Act are jointly and severally liable for payment of VAT relating to the entities covered by the joint registration. The same rule applies in Norway (see Section 7.1) and Sweden (see Section 7.3). The details are laid down in Section 47(4) of the Danish VAT Act ${ }^{63}$ :

"Upon request, two or more taxable persons which exclusively perform taxable activities can be registered together. The tax authorities may permit persons carrying on activities that are

60 MVA-loven § 2-2 (3) (Nor.).

61 Act relating to Value Added Tax [MVA-loven] [Norwegian VAT Act in English] § 2-2 (3). Translated by the Directorate of Taxes [RF - 0021] (Nor.).

62 Bekendtgørelse af lov om merværdiafgift (momsloven) [ML] [VAT Act] $\S 3$, sec. 3, § 46, sec. 9, and § 47, sec. 4. (LBK No 760 of June 21, 2016) (Den.).

63 The author's translation. 
subject to VAT registration to be registered together with persons whose activities are not subject to VAT registration and persons without economic activities. Such permission may only be granted if, via direct or indirect ownership, one person (parent company etc.) owns all the shares etc. in the other person(s) (subsidiaries, sub-subsidiaries etc.) which are covered by the joint registration. Only companies etc. that are established in Denmark may be registered jointly. An application for joint registration must be filed not later than one month before the joint registration is intended to take effect."

Denmark has not implemented rules to combat tax evasion and avoidance, as authorized by Article 11, second paragraph, of the VAT Directive (see Section 5.3, which is discussed in Section 8.1).

Since the first Danish VAT Act in 1967, the option for VAT groups existed as business entities that did not have the same owner could be registered jointly upon application. ${ }^{64}$ They would be jointly and severally liable for VAT. ${ }^{65}$ In the proposal for the rules, it was stated that the option allowed, for example, a parent company and a subsidiary to form a VAT group. ${ }^{66}$ Consequently, they should be treated as one business unit and no VAT should be imposed on transfer of goods between the companies. ${ }^{67}$ The travaux préparatoires to the original rules explains no further on the rationales, but this is explained much more in connection with the major change of the rules in 1994.

There appear to be many rationales for the Danish VAT grouping scheme that was introduced in 1994 in its current form based on Article 4(4) of the Sixth VAT Directive (see Section 5). ${ }^{68}$ In the proposal for the introduction of the rules, ${ }^{69}$ it was stated that there was a need to expand the option for joint registration/VAT grouping because of the increase in the number of groups of companies, especially in the financial sector. Thus, the intention was to ease the rules to allow groups of companies with both VAT liable and VAT-exempt activities to form a VAT group. ${ }^{70}$ There was an increase in the number of groups

64 Lov om almindelig omsætningsafgift [VAT Act] § 5, sec. 3. (Lov No 102 of March 31, 1967) (Den.).

65 Lov No 102 of March 31, 1967, § 24 (Den.)

66 Skatteministeriet [Danish Ministry of Taxation]: Redegørelse om Harmonisering af skatte- og afgiftsregler, May 1991, p. 198-200 [working group report] (Den.).

67 Forslag til Lov om almindelig omsætningsafgift [LF] LF of December 7, 1966, p. 318 [government bill] (Den.).

68 Forslag til Lov om merværdiafgift (momsloven) [LF] LF No 124, 1993/94 [government bill] (Den.).

69 LF No 124, 1993/94 (Den.).

70 Folketingstidende [FT] [Official publication of the Danish Parliament] Skriftlig fremsættelse of LF 124 of December 8, 1993, p. 3356 [written introduction of a bill] (Den.); and LF No 124, 1993/94 (Den.). of companies that involved a significant number of transactions between different companies within a group that were liable to VAT, such as office expenses, IT services, and administration. Thus, the purpose of the VAT grouping scheme was to enable transactions to take place between group members without these being liable to VAT. It was necessary to implement this via VAT grouping, as a few years previously the tax authorities' had terminated a former practice that allowed the reimbursement of internal group expenses without VAT Hansen (1994); Dekov (1995); Kirketerp (2001); Hansen and Dekov (1995). ${ }^{71}$ Reimbursement of internal group expenses could be seen as an administrative simplification for VAT groups, but this is not mentioned in the travaux préparatoires. Instead, the essential purpose-based on former administrative practice-appears to be the VAT saving obtained by group internal supplies not being subject to VAT.

From the travaux préparatoires, it is clear that the VAT grouping scheme was intended to relieve groups of companies, especially within the financial sector, of VAT on internal transactions and to continue or reintroduce a former beneficial tax practice on such internal transactions. This points to fiscal competition aspects, equivalent to the open discussion of these aspects in Sweden (see Section 7.3), but there is no word of it in the travaux préparatoires, nor is tax avoidance mentioned in the travaux préparatoires.

The stated purposes of the Danish VAT grouping scheme do not seem to be aligned with the purposes of the EU VAT grouping scheme (see Section 5), which should be the model for Denmark's implementation of its VAT grouping scheme. Denmark has not explicitly emphasized the purposes of administrative simplification, combating tax abuse or avoidance, or fiscal competition. Of course, these purposes may indirectly have been part of the considerations, but they are not expressly stated in the travaux préparatoires. On the contrary, the overall purpose appears to be to favor groups of companies, especially in the financial sector, by eliminating VAT on internal transactions. The Danish VAT grouping scheme is to be understood in this context.

Mirroring the criticism of Norway's $85 \%$ rule (see Section 7.1), there has been a discussion in Denmark about the legal reasons for the $100 \%$ rule. It has been argued that the $100 \%$ rule is disproportionate, as it is far stricter than the EU rule Eskildsen (2011); Brandt (2001); Dekov (1995); Hansen (1994). Presumably, the reason for the $100 \%$ rule is

\footnotetext{
Skatteministeriet [Danish Ministry of Taxation]: Rapport om Momsloven og 6. momsdirektiv, July 2001 [working group report] (Den.). 71 LF No 124, 1993/94 (Den.).
} 
to combat avoidance, as with Norway's $85 \%$ rule (see Section 7.1), but this is not directly stated in the proposal for the rules. ${ }^{72}$

It is interesting that both Denmark and Sweden (see Section 7.3) paid great attention to supporting the financial sector through their VAT grouping schemes. This shows that there was strong political support for the financial sector at the time of the introduction of the VAT grouping schemes, with fiscal competition implications mostly on a national level and also on an EU level in the situation of Sweden. These issues were directly addressed by Sweden (see Section 7.3) but not by Denmark.

\subsection{Swedish Rules on VAT Grouping}

As opposed to the Norwegian and Danish rules, the Swedish rules on VAT grouping contain many detailed provisions. The Swedish rules are in Chapter 6a of the Swedish VAT Act, ${ }^{73}$ from Paragraphs 1 to 7 . Only selected provisions of the rules are discussed for the purposes of this article.

The main rule is in Chapter 6a, Paragraph 1, of the Swedish VAT Act: ${ }^{74}$

"For the purposes of the application of the provisions of this Law, two or more economic entities may, in the circumstances stated in this chapter, be regarded as a single economic entity (VAT group), and the activity exercised by the VAT group may be regarded as a single activity."

However, the right to form a VAT group is restricted to groups of economic entities, primarily VAT exempted entities in the financial and insurance sectors; ${ }^{75}$ see Chapter 6 a, Paragraph 2, of the Swedish VAT Act ${ }^{76}$ :

"Only the following may be part of a VAT group:

1. economic entities, placed under the surveillance of the finance inspectorate which exercise an activity which is exempt because the turnover from that activity is exempt under Paragraph 9 or Paragraph 10 of Chapter 3,

2. economic entities whose main purpose is to deliver goods or provide services to the economic entities referred to in subparagraph 1 above, or

3. economic entities which are commission agents and principals, and which have a commission link such as

72 LF No 124, 1993/94 (Den.).

73 Mervärdesskattelagen [ML] [VAT Act] 6 a Chap. 1-7 §§. (SFS 1994:2000) (Swed.).

74 Case C-480/10 Commission v Sweden (English version).

75 ML 3 Chap. §§ 9-10 (Swed.).

76 Case C-480/10 Commission v Sweden (English version). that referred to in Chapter 36 of the law on income tax (1999:1229).”

The rationale for restricting VAT grouping primarily to the financial and insurance sectors is stated in the travaux préparatoires to the introduction of VAT grouping in 1999. ${ }^{77}$ The historical and political events leading up to the introduction of the VAT grouping scheme started in 1991 when a tax reform broadened the VAT tax base, increasing the VAT costs for VAT exempt businesses with nondeductible VAT inputs Alhager (2001), and Magnusson (1998). Representatives of the financial sector argued that this would have a major effect on the VAT costs of their internal organizations, as the VAT costs would be lower if their own personnel in VAT-exempt entities were to provide VATable services for their own needs rather than buying similar services from a closely related entity. ${ }^{78}$ The intention of the VAT grouping scheme was to enable entities in a group to be treated as a single entity for VAT purposes and thus avoid paying VAT on VATable transactions within a group. 79

In other words, the aim of the rules on VAT grouping was to enable business entities in a financial group that performs VAT-exempt financial activities to avoid paying nondeductible input VAT on purchases from other entities in the group Holmlund and Sundberg (2014); Kristoffersson (2009). ${ }^{80}$ This would ensure VAT neutrality between a concern's own production of normally VATable services and its purchase of such services from an external business entity. ${ }^{81}$ Also, different kinds of organizations in the financial sector could be subject to different VAT treatment of their internal transactions, resulting in distortion of competition Hefner (1998); Ek (2013). Thus, the financial sector would be particularly burdened by VAT on internal transactions resulting in a competitive disadvantage com-

77 Lag om ändring i mervärdesskattelagen (1994:200) [Amendment to VAT Act]. (SFS 1998:346) (Swed.).

78 Proposition [Prop.] 1997/98:148 Gruppregistrering i mervärdesskattesystemet, m.m. [government bill] (Swed.); and Departementsserien [Ds] 1997:80 Gruppregistrering av finansiella företag [Ministry Publications Series] (Swed.).

79 Prop. 1997/98:148, p. 22 (Swed.); and Ds 1997:80, p. 22 (Swed.). 80 Prop. 1997/98:148, pp. 1 and 94 (Swed.); and Ds 1997:80, p. 3 (Swed.); Promemoria RSV Dnr. 9115-98/900 om gruppregistrering enligt 6 a Chap. mervärdesskattelagen (1994:200), ML [Report from Ministry of Finance] (Swed.); betänkande [bet.] 1997/98:SkU29 Gruppregistrering i mervärdesskattesystemet [Committee Report] (Swed.); and Rättslig vägledning: Mervärdesskatt [RV] 2016 Mervärdesskattegrupp [Legal Guidelines] (Swed.).

81 Prop. 1997/98:148, p. 94 (Swed.). 
pared to financial companies in other EU countries, ${ }^{82}$ see Section 4.2.1.

Another purpose of VAT grouping stated in the travaux préparatoires is that support services within a financial group should not receive different VAT treatment than support services provided within a financial business. Thus, VAT grouping schemes are extended to entities within a group if their main activity is to provide the financial business with such services as they need for the provision of outgoing financial services. ${ }^{83}$ VAT grouping schemes cover more or less the entire financial and insurance sectors. It can be seen from this that fiscal competition aspects were seen as a major consideration in the travaux préparatoires. However, these considerations seem to be focused on achieving the highest possible level of fiscal neutrality within the financial and insurance sectors but not between these sectors and sectors outside the scope of the VAT grouping scheme. This is discussed further in Section 8.3.

In contrast to the Danish and Norwegian rules, the Swedish rules include several specific rules to prevent abuse and avoidance, such as

- The chosen administrative head of the VAT group for VAT purposes (grupphuvudman) is accepted by the tax authorities, provided there is no special reason (särskilda skäl) not to do so. ${ }^{84}$

- The tax authorities shall decide on formation of, changes to, or termination of VAT group registration upon the request of the parties involved, provided there is no special reason not to do so. ${ }^{85}$

- If the conditions for VAT group registration have ceased to exist, or for any other special reason, the tax authorities may terminate a VAT group registration on their own initiative. ${ }^{86}$

Hence, the tax authorities can decide on the formation of a VAT group, the admission of new members to a VAT group, the withdrawal of members from a VAT group, a change of the administrative head of a VAT group, and the termination of a VAT group. ${ }^{87}$ In particular, the right

82 Prop. 1997/98:148, pp. 27 and 30 (Swed.); Case C-480/10 Commission v Sweden, para. 26; and Regeringsrätten [RR] [Supreme Administrative Court] 2005-09-07, målnummer 2129-04 FöreningsSparbanken $A B$ (Swed.).

83 Prop. 1997/98:148, pp. 36 and 69 (Swed.).

84 ML 6 a Chap. $\S 4$ (Swed.).

85 ML 6 a Chap. $\S 6$ (Swed.).

86 ML 6 a Chap. $\S 6$ (Swed.).

87 ML 6 a Chap. $\S 5$ (Swed.). to terminate a VAT group is an effective measure for combating tax avoidance by the use of a VAT group.

There is guidance on the meaning of särskilda skäl in the travaux préparatoires. ${ }^{88}$ It is stated that the tax authorities shall only refuse an application for VAT group registration in special situations where an abuse of the VAT grouping scheme is obvious. It is also stated that the tax authorities should have the right to refuse VAT group registration if they consider that it could lead to tax evasion or avoidance or to obvious distortion of competition and that the tax authorities should have the right to dissolve a VAT group registration for the same reasons. ${ }^{89}$ No examples of such tax evasion or avoidance or obvious distortion of competition are given in the travaux préparatoires or in Swedish case law or administrative practice (see Section 8.3). The tax authorities' room for maneuver is limited, as only obvious cases of tax avoidance or distortion of competition qualify as special reason for applying the anti-avoidance rules. This is also discussed in Section 7.4. It will also be very difficult for the tax authorities to prove that there will be obvious tax avoidance or distortion of competition based on the information available at the time of application.

In its rationale for its VAT grouping scheme, Sweden has focused on both fiscal competition (particularly within the financial and insurance sectors) and tax avoidance and evasion. This is quite similar to Norway (see Section 7.1) but differs from the Danish rationale, which does not directly address the aspects of tax avoidance and fiscal competition (see Section 7.2). It can be concluded that there are very different rationales for the Nordic VAT grouping schemes and significant differences as to the weighting given to tax avoidance and fiscal competition, which will be demonstrated in practice (see Section 8). The next section discusses the effects of the different national rationales on the analysis of tax avoidance and fiscal competition in the Nordic VAT grouping schemes.

\subsection{The Effects of Different National Rationales}

On the basis of the examination of the different national rationales for the VAT grouping schemes in Norway (see Section 7.1), Denmark (see Section 7.2), and Sweden (see Section 7.3), as well as the EU rules that are only relevant

88 Prop. 1997/98:148, p. 73 (Swed.); and Ds 1997:80 (Swed.), pp. 8485.

89 RV 2016 Mervärdesskattegrupp (Swed.). 
for Denmark and Sweden (see Section 5), the further effects of the different rationales must be considered.

First, the different national rationales will affect opinions on whether or not there is tax avoidance in a concrete situation, as national differences in the underlying rationales inevitably influence opinions about tax avoidance in concrete cases.

In Sweden, the special anti-avoidance rules in the rules on VAT grouping only apply if there is obvious tax avoidance or abuse or obvious distortion of competition (see Section 7.3). Thus there is a high threshold for conduct to constitute tax avoidance or distortion of competition. This means that it will probably be seldom that the rights of VAT groups will be disregarded under the special anti-avoidance rules. In support of this view, see Section 8.3, where it is shown that there have been no cases where a VAT group has been rejected on these grounds. Also, tax avoidance cannot be established where the motivation for forming a VAT group is consistent with the purpose of a VAT grouping scheme, such as avoidance of payment of nondeductible input VAT on purchases from other group entities in the financial and insurance sectors (see Section 7.3). As for fiscal competition, the distortion of competition between entities in the financial and insurance sectors and other taxable persons operating on the same market is (for now; see Section 8.3) a legitimate purpose (see Section 7.3), whereas other kinds of distortion of competition may not be equally legitimate.

Some of the same things can be said about Denmark, where the rationale for the VAT grouping scheme was to relieve groups of companies from paying VAT on internal transactions (see Section 7.2). Thus, the mere motivation of avoiding paying VAT, for example, by reducing direct or indirect VAT costs, does not in itself constitute tax avoidance in the context of the rules on VAT grouping Vyncke (2007).

There is the same picture in Norway where a VAT group's intention of avoiding paying VAT on internal supplies within the group is not in itself considered to be tax avoidance or abuse Gjems-Onstad and Kildal (2013); Bråthen et al. (2012); Gjems-Onstad (2009), because this is consistent with the rationale for VAT grouping schemes. Another legitimate purpose is related to the fixed threshold of $85 \%$ ownership, where tax avoidance cannot be established if a company acquires shares with the aim of fulfilling the 85\% rule Fjermeros (2014); Killengreen et al. (2000a). See also Swinkels (2010).

Consequently, for conduct to constitute tax avoidance or abuse in the area of VAT grouping, it must go beyond the legitimate purposes of VAT grouping schemes Doesum et al. (2016) and must involve conduct where a VAT group- ing scheme is misused in order to obtain unintended VAT advantages. VAT grouping will not be accepted in such situations Gjems-Onstad and Kildal (2013) or in situations based on artificial arrangements Vyncke (2007); Pfeiffer (2015a).

Reflecting the high threshold for conduct to constitute tax avoidance in Sweden, from a Norwegian point of view, Ole Gjems-Onstad and Tor S. Kildal have argued that the threshold for a finding of VAT avoidance should be high, given that the VAT system is a self-declaration system imposing comprehensive obligations on taxable persons; this presupposes that the rules are foreseeable and clear Gjems-Onstad and Kildal (2013).

The above findings on tax avoidance and fiscal competition are based on the analyses of the different national rationales for the Nordic VAT grouping schemes, which must be taken into account in the integrated contextual and teleological part of the analysis of the risks of tax avoidance and fiscal competition that follows.

\section{Risks of Tax Avoidance and Fiscal Competition in Practice}

This section contains analyses of national case law and administrative practice in Denmark, Norway, and Sweden, starting with the most substantial cases that show clear signs of tax avoidance or fiscal competition connected with VAT grouping.

\subsection{The Danish Focus on VAT Abuse in VAT Groups}

In Danish administrative practice, recently, there has been an increased focus on the aspects of tax abuse and tax avoidance in connection with the use of VAT groups leading to an otherwise VATable transaction being not subject to VAT. The most relevant cases involving aspects of tax avoidance and fiscal competition are analyzed, first in relation to real property (see Section 8.1.1) and then in relation to IT systems (see Section 8.1.2). 


\subsubsection{VAT Groups and Real Property}

A published binding ruling of the Danish Tax Council, ${ }^{90}$ SKM2015.530.SR, ${ }^{91}$ made clear the Council's opinion on tax avoidance issues in relation to a VAT group and real property transactions. ${ }^{92}$

In 2011, Denmark introduced VAT liability for real property transactions, ${ }^{93}$ among other things, by implementing Article 12(1)(a)-(b) of the VAT Directive Elgaard (2016a). Prior to 2011, Denmark had maintained a VAT exemption for real property transactions dating back to 1978, based on Article 371 of the VAT Directive and its Annex X, Part B, point 9.

The Tax Council did not directly determine that the VAT group was an abuse of the VAT grouping scheme, but it strongly indicated that the model would probably be considered as abuse based on the facts. Following the Council's ruling, the administrative practice on special VAT groups for real property will probably be stricter.

The administrative practice will probably be stricter because the applicant who applied for the binding ruling in SKM2015.530.SR relied unsuccessfully on two previously unpublished binding rulings of the Danish tax authorities (SKAT) on a similar VAT group, given in 2013. According to the applicant, SKAT accepted the VAT group in the unpublished cases without expressing concern about VAT abuse. SKM2015.530.SR suggests that the Tax Council focuses more than SKAT on the risks of VAT abuse and avoidance of paying VAT in VAT groups involved in transactions of real property. ${ }^{94}$ Presumably, areas other than real property could be affected by a stricter administrative practice if VAT groups were to be used in the same way as in SKM2015.530.SR.

The VAT group model used in SKM2015.530.SR was as follows. Company S1, the applicant for the binding ruling, owned real property in the form of building sites. (Trans-

90 The Danish Tax Council (Skatterådet) is part of the Danish tax administration: Bekendtgørelse af skatteforvaltningsloven [SFL] [Tax Administration Act] Chap. 2. (LBK No 1267 of November 12, 2015) (Den.)

91 Skatterådet [SR] [Tax Council] August 10, 2015, SKM2015.530.SR (Den.).

92 A similar VAT group model in relation to transfer of specific tangible or intangible property was described by Swinkels (2010).

93 Lov om ændring af lov om merværdiafgift og lov om afgift af lønsum m.v. [Ændring af momsloven] [Amendment to VAT Act]. (Lov No 520 of June 12, 2009) (Den.).

94 In Momskontaktudvalget's [VAT Contact Committee] minutes of March 7, 2016, Section 9 (Den.), the Danish tax authorities replied in relation to SKM2015.530.SR that SKAT in some of those cases had seen indications of abuse of the VAT rules. actions involving building sites are subject to Danish VAT).

${ }^{95} \mathrm{~S} 1$ intended to transfer the building sites to development companies in order to carry out site development together with external investors. The transfer of the building sites was to be carried out in several steps. First, S1 would incorporate the development companies as wholly owned subsidiaries. Then $\mathrm{S} 1$ and the subsidiaries would apply for VAT grouping. When permission for VAT grouping was obtained, the building sites would be transferred to the subsidiaries as contributions in kind.

Among other things, the applicant's stated purpose for the incorporation of the development companies was to limit and share the risks of the site development of the individual building sites with the co-applicant for the binding ruling, company S2, which was an external investor.

The next step was to form a new holding company with a share exchange between $\mathrm{S} 1$ and the new subsidiaries, after which the holding company would apply to become a member of the VAT group. This would be followed by the transfer of $50 \%$ of the share capital in the holding company to S2 or an existing wholly owned subsidiary of S2. S1 could no longer be part of the VAT group because of the requirement for $100 \%$ ownership (see Section 7.2). The site development would then be carried out by the development companies, and the VAT group consisting of the holding company and the development companies would at least be maintained during the whole of the site development phase.

Among other things, the applicant's stated purpose with the holding company was to join forces on the building project, secure S1's influence in the planning and site development phase, and share the commercial risks of the site development and subsequent sale between S1 and S2. In the longer term, the purpose of S1's participation was to dispose of the building sites.

In considering this, the Danish Tax Council did not directly answer to the applicant's key question as to whether, as a whole, the model would be accepted by the tax authorities. The reason for this was that, legally speaking, an application for VAT grouping is an application for a license, and this is outside the scope of the binding ruling system. ${ }^{96}$ Thus the Tax Council did not have the capacity to give a binding ruling on this.

From a taxpayer's point of view, and considering the general principle of equal treatment, it may seem inconsistent that, as claimed by the applicant, a few years ago,

95 ML § 13, sec. 1, subsec. 9 (Den.). 96 SFL $\S 21$, sec. 3 (Den.). 
SKAT had accepted similar VAT group models in two unpublished binding rulings, thereby ignoring the license question. However, the license question is not relevant for the purpose of this article; what is relevant is the Tax Council's opinion on VAT abuse and avoidance in connection with VAT groups.

The Tax Council's clear opinion was expressed several times in its answer to the applicant's request for a binding ruling. First, the Council determined that the transfer of the building sites to the development companies after the establishment of the VAT group resulted in S1 not paying VAT on the transaction. As the subsequent sale of the shares later would be exempt from VAT, ${ }^{97}$ the VAT liability on the building sites would be eliminated and, at a later stage, the real property could also be sold as VATexempt "old buildings" covered by the VAT exemption. ${ }^{98}$ In the light of this, the Council stated that the transfer of the building sites immediately after the establishment of a VAT group must be seen as indicating abuse of the rules on VAT grouping.

The Tax Council also pointed out that there was no commercial purpose behind making the transfer of the building sites a contribution in kind after the incorporation of the development companies, and the Council considered that the only reason for this was to avoid paying VAT, thereby the Council dismissed the arguments for commercial reasons brought forward by the applicant. The Council concluded that a VAT group should not affect the transaction. ${ }^{99}$

While it was not explicitly established in SKM2015.530.SR that the VAT group model was unacceptable on the ground that it constitutes VAT abuse, the case will still have a powerful dissuasive effect. Presumably, taxpayers will be unwilling to risk being associated with VAT abuse by using an uncertain VAT group model when the Tax Council has given such a clear public opinion.

The timing of the establishment of the VAT group was also an element in SKM2015.530.SR. The EU Commission has expressed the view that Article 11, second paragraph, of the VAT Directive allows for measures aimed at ensuring that no unjustified advantage is derived from a VAT grouping scheme (see Section 5), for example, by setting a mini-

97 ML § 13, sec. 1, subsec. 11, litra e (Den.).

98 VAT-taxable supplies are supplies of new buildings or building sites. ML §13, sec. 1, subsec. 9 (Den.).

99 In a later case, SKM2015.707.SR, the Danish Tax Council stated that there would be no basis for considering aspects of avoidance of the VAT grouping rules in relation to a sale of real property within a VAT group regardless of the intention to sell the shares afterwards as the sale would be VAT-exempt inside as well as outside a VAT group. mum duration for VAT groups. ${ }^{100}$ SKM2015.530.SR reflects this view, as the Tax Council emphasized that the transfer of the building sites took place immediately after the establishment of the VAT group, which indicated that there was abuse. In support of this, Eleonor Kristoffersson (formerly Alhager) has said that if VAT groups are relatively fixed in character, probably also in terms of duration, the scope for using them for tax avoidance purposes would be minimized Alhager (2002). Thus, the timing element in the formation of VAT groups must be considered an important factor when determining whether there is tax abuse and avoidance.

Another question in SKM2015.530.SR was whether the refusal of an application for a VAT grouping necessitated a legal basis in the form of specific Danish anti-avoidance rules, as in Sweden (see Section 7.3), or whether the general VAT anti-abuse doctrine derived from the EU case law, including the Halifax case ${ }^{101}$ (see Section 4.1), is a sufficient legal basis for refusing applications for VAT grouping. In Norway, the question may be more related to whether gjennomskæring could be applied to the whole set of dispositions (see Section 4.1.2).

In this regard, the Danish Tax Council noted that attaining a better VAT position by applying the VAT grouping rules is not in itself an abuse of the rules. It is only insofar as the general EU VAT anti-abuse doctrine is effective on the case that the application of the VAT grouping rules can constitute abuse. According to the Tax Council, given the principle of interpretation of national laws so as to be consistent with the EU legislation and given the principle of the supremacy of the EU law and the EU case law, the EU VAT anti-abuse clause will be applicable to the formation of VAT groups. In the same way, an existing VAT group can be dissolved with effect for existing arrangements, provided it can be shown that there has been VAT abuse.

The present author agrees with the arguments of the Tax Council in SKM2015.530.SR (see Section 5). Where abuse or avoidance can be established, taxpayers do not have a right to form a VAT group even if all the objective conditions are fulfilled. In any event, it may be quicker and more effective to have specific anti-avoidance rules similar to the Swedish rules (see Section 7.3) than to rely on the general EU VAT anti-abuse doctrine and the inherent formal, substantive, and evidential requirements.

There is no example of a VAT group model similar to that in SKM2015.530.SR, in the published case law, ad-

$\overline{100 \operatorname{COM}(2009)} 325$ final of July 2, 2009, p. 11. 101 Case C-255/02 Halifax. 
ministrative practice, or legal literature in Norway or Sweden. Thus this is not a present problem in Sweden or Norway, but it may become a problem, not only for the Nordic countries but also for other countries with VAT grouping schemes similar to the VAT group model in Denmark.

\subsubsection{VAT Groups and IT systems}

Another area in which the Danish tax authorities have recently observed tax avoidance is in relation to VAT groups and IT systems. New VAT rules were adopted on this in $2014^{102}$ to combat tax avoidance by means of a specific anti-abuse rule in the Danish VAT Act. In the proposal for the new rule, ${ }^{103}$ it was noted that in its tax controls, SKAT had seen examples of abuse of the rules on VAT grouping, and while the examples were few in number, the amounts involved were significant.

The VAT group model for IT systems is as follows. A company needs a new IT system. The company has primarily VAT-exempt activities and thus has no right or very little right to make VAT deductions. If the company pays for the development of a system by another company, the first company would have no right or only a limited right to deduct input VAT. Instead, the company forms a subsidiary that develops or purchases the system and leases it to the parent company. As the rental is liable to VAT, the subsidiary can deduct input VAT. After a short period, a VAT grouping of the parent company and the subsidiary is applied for, after which the rental will become an internal transaction and not subject to VAT. By using this model, the company obtains a right to deduct almost all the input VAT on the purchase of the IT services. ${ }^{104}$

The proposal for the new rules suggested including IT services (with similar characteristics to ordinary capital goods such as long-term use and depreciation) in the definition of the capital goods scheme and the five-year adjustment period. ${ }^{105}$ This would effectively and considerably minimize the VAT advantage of the VAT group model. The VAT group model in relation to IT systems, which is

102 Lov om ændring af momsloven og forskellige andre love [Ændring af momsloven] [Amendment to VAT Act]. (Lov No 554 of June 2, 2014) (Den.).

103 Lovforslag [LF] LF No 153, 2013-14, Section 3.3.1.2 [government bill] (Den.).

104 A similar VAT grouping model in relation to leasing of busses was described by Engers (1996) and in relation to purchase of expensive goods, for example, medical equipment or customized software, by Swinkels $(2005,2010)$.

105 ML §§ 43-44 (Den.). not acceptable to the tax authorities, also shows that VAT group models can be legitimately combined with the rules of the capital goods scheme without constituting tax abuse or avoidance. However, the evaluation of abusive elements of a combination of a VAT grouping scheme and a capital goods scheme would depend on the timing and the national jurisdiction of the case in question because this combination by some would be considered to be avoidance (see Swinkels (2010)).

\subsection{Norwegian Examples of Abuse in Relation to VAT Grouping}

Ole Gjems-Onstad and Tor S. Kildal point out that the rules on VAT grouping are one of the two sets of rules in which the application of the Norwegian general antiavoidance clause (see Section 4.1) may be most relevant in the area of VAT Gjems-Onstad (2016); Gjems-Onstad and Kildal (2013); Gjems-Onstad (2009). ${ }^{106}$ In spite of this, there have been no clear examples of such tax avoidance in Norwegian case law. Thus, examples of tax avoidance in connection with VAT grouping discussed in Norwegian legal literature are hypothetical Bråthen et al. (2012).

\subsubsection{VAT Groups Consisting of Sellers and their Customers}

Ole Gjems-Onstad and Tor S. Kildal give the example of a hypothetical transactional relationship in which the seller is a taxable person under the Norwegian VAT Act and the customer is not registered under the VAT Act and has no right to deduct VAT Gjems-Onstad and Kildal (2013). If a seller and a customer enter into a joint ownership arrangement and form a VAT group, the seller's supplies to the customer will be outside the scope of VAT. In the opinion of Gjems-Onstad and Kildal, tax avoidance could be shown to exist if it can be demonstrated that ownership is a reversed customer relationship that serves no purpose other than avoiding VAT. As stated by these authors, the reason for this is that a VAT grouping is intended to enable avoidance of payment of VAT in real internal group relations and where there is genuine joint ownership. A VAT grouping is

$\overline{106}$ NOU 2016:5, p. 72 (Nor.) mentions VAT grouping as an example where the proposed general anti-avoidance clause would be applicable in order to prevent practice aiming at obtaining unintended VAT advantages. 
not intended to be used in an ordinary buying and selling relationship Gjems-Onstad (2009); Bråthen et al. (2012). ${ }^{107}$

The Norwegian legal literature refer to a media report of a case ${ }^{108}$ involving a bank that had to repay the tax authorities the nondeductible VAT on the hiring of labor from a temporary employment agency Gjems-Onstad and Kildal (2013); Bråthen et al. (2012); Mikelsen (2016). The bank had agreed with the agency to incorporate a jointly owned company. It was reported that the bank owned $85 \%$ of the company and the agency owned $15 \%$. The bank had then established a VAT group with the jointly owned company that supplied the services to the bank, but the bank only received $15 \%$ or no dividend from the jointly owned company. According to the media reports, the jointly owned company shared a workplace and central office with the agency, and the bank was the jointly owned company's only customer Bråthen et al. (2012). ${ }^{109}$

If these facts are correct, Ole Gjems-Onstad and Tor S. Kildal say that the situation need not be treated as tax avoidance, but merely treated on the basis that the cash flow had not been allocated correctly. Thus, these authors suggest a solution based on the reality of transactions and not one based on the application of the general antiavoidance clause in Norwegian law Gjems-Onstad and Kildal (2013); Gjems-Onstad et al. (2016).

Gisle Bråthen, Erik Frøystad, and Ole Martin Haugan are of the opinion that the avoidance of payment of VAT seemed to be almost the sole purpose of the incorporation of the jointly owned company and the formation of the VAT group Bråthen et al. (2012). According to these authors, a finding of tax avoidance must be based on an evaluation of the principle of loyalty as expressed in Norwegian case law (see Section 4.1.2). They argue that registering a VAT group in order to save VAT is not in itself evidence of tax avoidance because a VAT grouping may justly result in VAT savings in real group and joint ownership relations GjemsOnstad (2009) (see Section 7.4). However, Bråthen, Frøystad, and Haugan argue that in the case reported in the media and referred to above, the transactions should be seen as a whole. The incorporation of the jointly owned com-

107 Several VAT avoidance schemes concerning "customers" not entitled to deduct input VAT or its right to deduct input VAT are described by Swinkels (2005, 2010).

108 Further references to the case from the media have not been found.

109 Another VAT avoidance scheme involving the formation of a joint venture, for example, regarding construction of buildings, exploitation of intangible assets, development of customised software or provision of cleaning staff in the health care and education sectors, is described by Swinkels (2010). pany and the formation of the VAT group were aimed at changing a customer relationship into a company relationship, thereby giving grounds for a finding that there was tax avoidance Bråthen et al. (2012).

From this author's point of view, and taking into account the Danish practice (see Section 8.1), such a formation of a VAT group between a seller and a customer was undeniably inconsistent with the reality of the arrangement, and the group should be disregarded for VAT purposes on the ground of tax abuse or avoidance. However, in future, the result will depend on the facts and whether the Norwegian criteria for constituting abuse of the VAT grouping rules have been fulfilled, or the case would be decided on pro forma (see Section 4.1.2).

\subsubsection{Cooperating Companies in Norwegian Law}

Another area of VAT grouping in which potential tax avoidance may be seen concerns the criteria for "cooperating companies" to be allowed to form a Norwegian VAT group (see Section 7.1). A letter from the Norwegian Directorate of Taxes of November 18, 2008, concerned the right to deduct a company's purchase of advisory services in connection with buying all the shares in another company in order to register for VAT grouping. ${ }^{110}$ The Directorate of Taxes refused to allow such a right as the conditions for making a deduction had not been met. The Directorate noted that it appeared from the facts that the first company only seemed to function as the owner of the second company. Thus, the Directorate questioned whether the companies actually were "cooperating companies" and whether the sole intention of registering as a VAT group was to obtain relief from paying VAT on costs connected with the acquisition of the shares.

The case gives a discreet indication of potential tax avoidance aspects connected with the criteria for cooperating companies. As such, the criteria for "cooperating companies" may be seen as a tool for testing tax avoidance in connection with VAT groups (see Section 7.1). In this author's opinion, the cooperative criteria could also be seen merely as a means for examining whether the commercial and organizational conditions for VAT grouping have been objectively fulfilled. In that case, an objective evaluation of the criteria would not include any tax avoidance aspects. To some extent, this is supported by a Swedish case, RÅ

110 Skattedirektoratet's [Directorate of Taxes] letter of November 18, 2008, to Skatt Nord [USKD-2009-1] (Nor.). 
2005 not 106, ${ }^{111}$ in which a thorough examination of a cooperative link for Swedish VAT grouping did not indicate tax avoidance.

\subsection{Swedish Focus on Fiscal Competition Issues}

No clear examples of tax avoidance in relation to VAT grouping have been found in Swedish case law, administrative practice, or legal literature. In several places, there is a general comment that VAT groups may be used for tax avoidance purposes, for example, in the travaux préparatoires (see Section 7.3) and in Swedish legal literature Selting (2010); Alhager (2002), but no concrete examples are given. Thus, in Swedish practice, there is a low risk of VAT groups being found liable for tax abuse or avoidance.

The low risk of a finding of tax avoidance may be because in Sweden VAT groups are primarily used in the financial and insurance sectors, thereby limiting their use to business sectors that are already subject to extensive regulation and state control Swinkels (2010); Alhager (2001). Another reason may be that generally, the high focus on the fiscal competition aspects of VAT groups may have shifted the focus from tax avoidance (see Section 7.3). This suggestion is to some extent supported by Case C-480/10 Commission v Sweden and the 2014 proposal to abolish VAT grouping (see below).

In Swedish case law, practice, or legal literature, no cases have been found constituting distortion of competition, although fiscal competition issues were part of the discussions in decision No 2129-04 from the Supreme Administrative Court, FöreningsSparbanken $A B,{ }^{112}$ regarding deregistration of a VAT group because of lack of fulfilling the financial, economic, and organizational link. ${ }^{113}$ The VAT group argued in vain that no special reason could give ground for deregistration (see Section 7.3) and that deregistration would result in a competitive disadvantage compared to other organizations allowed for VAT grouping. However, the Court decided the case solely on whether the objective conditions for VAT grouping were fulfilled, which made issues on fiscal competition irrelevant for the case.

111 Regeringsrätten [RR] [Supreme Administrative Court] 2005-0601, RÅ 2005 not 106 FöreningsSparbanken $A B$ (Swed.). See also Regeringsrätten [RR] [Supreme Administrative Court] 2005-09-07, målnummer 2129-04 FöreningsSparbanken $A B$ (Swed.).

112 Regeringsrätten [RR] [Supreme Administrative Court] 2005-0907, målnummer 2129-04 FöreningsSparbanken $A B$ (Swed.). 113 ML 6 a Chap. $3 \S$ (Swed.).
The main issue in Case C-480/10 Commission v Sweden was whether the sector-specific restriction of Swedish VAT groups to the financial and insurance sectors was in conflict with the VAT Directive. The CJEU ruled that the Swedish rules were acceptable and within the margin of discretion of the VAT Directive (see Section 1.3), as the rules legitimately prevented tax abuse and avoidance Karlsson and Schiess (2013); Ek (2013). ${ }^{114}$ Obviously, Sweden succeeded in its arguments that sector-specific restrictions are permissible for the purposes of combating tax abuse and avoidance under Article 11, second paragraph, of the VAT Directive, even though these arguments are not directly stated in the travaux préparatoires to the Swedish rules (Ek 2013) ${ }^{115}$ (see Section 7.3).

In 2014, a proposal was made ${ }^{116}$ to abolish the Swedish VAT grouping scheme Kristoffersson (2016), but it has not been adopted. The arguments for the proposal were that it distorted competition in favor of the financial sector and was prejudicial to other taxable sectors and that the tax advantage affected a greater part of society's resources than was socioeconomically optimal Holmlund and Sundberg (2014). ${ }^{117}$ The proposal illustrates the criticism of giving VAT advantages to VAT groups. The abandoned proposal made no mention of tax abuse or avoidance; the whole purpose of the proposal was to prevent distortion of competition between businesses in general.

\section{Comments on VAT Grouping and Joint Income Taxation}

From a Danish point of view, the rules on VAT grouping are naturally associated with the rules on joint income taxation, as some of the functions and legal effects of the VAT and the income tax schemes are superficially similar. For example, both the VAT and the income tax schemes allow group consolidation for VAT and income tax purposes, ${ }^{118}$

114 RV 2016 Mervärdesskattegrupp (Swed.).

115 Prop. 1997/98:148 (Swed.); and Ds 1997:80 (Swed.).

116 Departementsserien [Ds Fi] 2014 Vissa skattefrågor inför budgetpropositionen för 2015 [Ministry Publications Series the Finance Department] (Swed.). Lagrådsremiss [Proposal to the Council on Legislation] Vissa skattefrågor inför budgetpropositionen för 2015 [Finance Department] (Swed.).

117 Ds Fi 2014 Vissa skattefrågor inför budgetpropositionen för 2015, p. 48 (Swed.).

118 Selskabsskatteloven [SL] [Corporation Tax Act] §§ 31-31A. (LBK No 1164 of 06/09/2016) (Den.). ML § 3, sec. 3 (Den.). Den juridiske vejledning 2016-2 [DJV] Section D.A.3.3.1 [Legal Guidelines] (Den.). 
the appointment of an administrative head of the group, ${ }^{119}$ joint and several liability for taxes, ${ }^{120}$ and more. Martin Jensen has observed that joint VAT and income tax schemes are relatively comparable, as joint income taxation results in lower taxation for the group as a whole by enabling losses to be set off against profits, while the purpose of a VAT group is to allow VAT exemption for internal supplies while allowing a generally higher partial right of deduction Jensen (2009).

My $\mathrm{PhD}$ project has demonstrated that there is often a close and quite extensive interaction between VAT law and income tax law in Danish law Elgaard (2016a). It is thus natural to compare VAT grouping with joint income taxation, and this could justify making an in-depth analysis of the two, which could provide useful insights, drawing lessons from VAT grouping and applying them to income tax schemes and vice versa. However, I believe that this idea should not be pursued in the form of a comparative analysis for the following reasons.

The apparent comparability of VAT grouping and joint income taxation becomes less apparent in the context of the Swedish and Norwegian rules on the tax treatment of groups of companies. In contrast to Denmark, which uses a model in which the profits and losses of a group are combined to produce a consolidated computation Parolini (2008), the Swedish rules are based on a model using a koncernbidragsrätt Lodin et al. (2015); Baekkevold et al. (2010); Wiman (1991, 2002); Kristoffersson (2016) and the Norwegian rules are based on a model using a fradrag for konsernbidrag Aasen and Lorentzen (2008a,b). In both cases, this means that group contributions are made with a right to make deductions.

Both the Swedish and the Norwegian rules on group contributions with a right to make deductions ${ }^{121}$ are aimed at achieving profit equalization of the taxable results within a group in order to reduce the tax burden on the group as a whole by setting off losses against profits by transfers of payments within the group Harris (2013). Hence, the Swedish and Norwegian models entail making group contributions with right for the contributor to make a deduction and with corresponding tax liability for the recipient Gerson (2011); Douma and Naumburg (2006); Ståhl (2000); Bergström and Bruzelius (2001); Brandt (1999,

119 SL $\S 31$, sec. 6 (Den.). 120 SL $\S 31$, sec. 6 (Den.). ML § 46, sec. 9 (Den.).

121 Inkomstskattelagen [IL] [Income Tax Law] Chap. 35. (SFS 1999:1229) (Swed.). Lov om skatt av formue og inntekt (skatteloven). Skattlegging av aksjeselskap og allmennaksjeselskap m.v. [Skatteloven] [Tax Act] Chap. 10. (LOV-1999-03-26-14) (Nor.).
2000); in other words, the scheme involves a transfer of funds between group companies without any consideration Wiman (2002); Aasen and Lorentzen (2008a,b).

This means, from a Nordic perspective, that the fundamental conditions for establishing comparability between VAT grouping and joint income taxation do not exist, primarily because the Swedish and Norwegian joint income taxation schemes differ significantly from the Danish joint income taxation scheme. The apparent similarities between the Danish VAT grouping scheme and the joint income taxation scheme do not exist in Sweden or Norway, because Sweden and Norway do not use a joint income taxation model based on the complete consolidation of a group for income tax purposes.

Martin Jensen concluded his analysis of the "hypothetical analogy" between the rules on VAT grouping and the rules on joint income taxation by clearly stating that the analogy cannot be upheld and that an analogous application of the case law on joint income taxation cannot give guidance in the area of VAT (Jensen (2009), and in the same direction Henkow (2009); Elgaard (2016a). Ole Gjems-Onstad has also made a brief comparison of joint income taxation groups and VAT groups with reference to the fact that in both cases, there is voluntary group registration, enabling several legal persons to be treated as a single taxable person. However, he stresses that the rules must be presumed to be different in nature Gjems-Onstad (2012). See also Parolini et al. (2011); Kolozs (2009), with which I certainly agree Elgaard (2016a).

The above considerations mean that there is no basis for making a comparative analysis of VAT grouping schemes and joint income taxation schemes that could reasonably prove useful for further research or for this article. However, a purely national analysis of the VAT grouping scheme compared to the joint income taxation scheme may be relevant for other purposes than this.

\section{Conclusions and Considerations}

On the basis of a comparative analysis of VAT grouping schemes in Denmark, Norway, and Sweden, it can be concluded that, both in theory and in practice, there is a real risk of tax abuse and avoidance connected with the use of various VAT group models. The risk is especially clear in Denmark in the areas of real property and IT systems (see Section 8.1) and, in some cases, in Norway in connection with converting seller/customer relationships into VAT groups (see Section 8.2). 
Denmark and Norway have added some minor special anti-avoidance measures to the rules on VAT groups in the form of ownership percentage rules (see Sections 7.1 and 7.2). This is probably due to the relative de-emphasizing of tax abuse and tax avoidance in the travaux préparatoires for their VAT grouping schemes. As for the analysis of the rationales for the national VAT grouping schemes in Denmark and Norway (see Sections 7.1 and 7.2), the main stated purpose was not to combat tax abuse and avoidance but to grant VAT exemptions on internal supplies within groups of companies (primarily financial groups) and the full right of cooperating companies to make deductions.

In contrast to Denmark and Norway, Sweden has implemented detailed rules to prevent abuse and avoidance as an integral part of its rules on VAT grouping (see Section 7.3). This implies that Sweden has focused on combating tax abuse and avoidance from the start. This is supported by the travaux préparatoires and the core rationale for restricting VAT grouping to the financial and insurance sectors (see Section 7.3). This appeared to be accepted by the CJEU in Case C-408/10 Commission v Sweden (see Section 8.3). As there have been no concrete examples of tax abuse or avoidance connected with VAT grouping in Swedish case law, administrative practice, or legal literature, it is reasonable to suggest that the special anti-avoidance rules combined with the restriction of VAT grouping to the financial and insurance sectors may have had a positive effect in practice.

However, the positive effect must be weighed against fiscal competition aspects, as restricting of the scope of VAT grouping to the financial and insurance sectors raises problems of distortion of competition in relation to businesses outside these sectors competing on the same market that are not eligible for the benefits of VAT grouping. ${ }^{122}$ Such competing businesses with no access to VAT grouping could, for example, be support services suppliers (see Section 7.3) or other banks such as FöreningsSparbanken $A B$ (see Section 8.3). These considerations are referred to in the travaux préparatoires to the Swedish rules and more recently in the proposal to abolish the VAT grouping scheme with explicit reference to the negative effects of distortion of competition (see Section 8.3). The CJEU confirmed the priority of combating tax avoidance over the prevention of fiscal competition in Case C-480/10 Commission $\mathrm{v}$ Sweden. Whether this priority is reasonable in all

122 National regulation aiming at compensating for the lack of access to VAT grouping are not included in the article, as this is outside the scope of the research purpose of the article (see Section 2.2), and it would be too extensive to include in the article. cases is open to question, even though it seems reasonable on the face of it. However, this must be determined on a case-by-case basis.

Norway actively dealt with competition issues in the travaux préparatoires to its VAT grouping scheme, as achieving competition neutrality was a high priority for the rules (see Section 7.1). There seem to be no major problems of distortion of competition in practice, though there has been criticism in the legal literature of the distorting effect of the $85 \%$ rule, which exclude companies that do not fulfill this criterion for VAT grouping (see Section 7.1). ${ }^{123}$ However, as the $85 \%$ rule is a general rule, applying to all business entities, the rule is the same for all and should not in itself distort competition.

In Denmark, fiscal competition has not received much attention either during the legislative process or in practice (see Sections 7.2 and 8.1). The competition aspect was unquestionably an important reason for introducing the Danish VAT grouping scheme, but this was not directly expressed in the travaux préparatoires (see Section 7.2). The lack of case law or administrative practice on fiscal competition could indicate that the more important problem in Denmark concerns tax abuse and avoidance (see Section 8.1), rather than distortion of competition.

While this comparative analysis of the VAT grouping schemes in the Nordic countries is extensive, it is impossible to cover all aspects in depth within the scope of this article. The findings of this article are important, as the article has shown that in all three Nordic countries, there are in fact problems and risks related to tax avoidance and distortion of competition. This article also demonstrates that aspects of tax avoidance and fiscal competition are interconnected and that it is necessary to weigh them against each other in relation to VAT grouping schemes.

\section{References}

Alhager, Eleonor. 2001. Mervärdesskatt vid omstruktureringar. Uppsala, Sweden: Iustus Förlag.

Alhager, Eleonor. 2002. “Kringgående av moms”. Skattenytt: 104114.

Amand, Christian. 2013. "VAT neutrality: a principle of EU law or a principle of the VAT system?". World Journal of VAT/GST Law 2 (3): 163-181.

Andersson, Krister \& Johan Fall. 2001. "Financial Markets and Tax Competition". In Liber Amicorum Sven-Olof Lodin, edited by Krister Andersson, Peter Melz \& Christer Silfverberg, 21-39. Stock-

123 Same viewpoint has been raised regarding the $100 \%$ rule in Denmark Westberg (1994). 
holm, Sweden: Kluwer Law International.

Arnold, Brian. 1997. "The Canadian General Anti-Avoidance Rule”. In Tax Avoidance and the Rule of Law, edited by Graeme S. Cooper, 221-245. Amsterdam: IBFD.

Ault, Hugh J. 1999. "Tax Simplification from a Comparative Point of View". In International Studies in Taxation: Law and Economics, Liber Amicorum Leif Mutén, edited by Gustaf Lindencrona, SvenOlof Lodin \& Bertil Wiman, 29-44. London, United Kingdom: Kluwer Law International.

Ault, Hugh J. 2002. "Tax Competition: What (If Anything) To Do About It?". In International and Comparative Taxation, Essays in Honour of Klaus Vogel, edited by Kees van Raad, 1-8. London, United Kingdom: Kluwer Law International.

Baekkevold, Arne et al. 2010. Inkomstskatt - en lagkommentar. Stockholm, Sweden: Thomson Reuters.

Bergström, Sture \& Anette Bruzelius. 2001. “Home-State Restrictions on the Freedom of Establishment in a Swedish Income Tax Law Perspective". Intertax 29 (6/7): 233-241.

Bjørnholm, Nikolaj \& Mette Juul. 2015: "Uklarheder efter Skandiadommen". Skat Udland: 314.

Brandt, Peter. 1999. "Tax Rules on Company Reorganizations - Some Cross-Border Aspects”. European Taxation (11): 433-443.

Brandt, Peter. 2000. “Sweden”. European Taxation (1/2): 77-82.

Brandt, Ulla. 2001. “Momsmæssig fællesregistrering i et nationalt og EU-retligt perspektiv". Skat Udland: 358-362.

Bråthen, Gisle, Erik Frøystad \& Ole Martin Haugan. 2012. "Fellesregistrering i Norge og EU". In Praktisk merverdiavgiftsrett, edited by Ole Gjems-Onstad, Cecilie Aasprong Dyrnes \& Tor S. Kildal, 41-59. Oslo, Norge: Gyldendal Juridisk.

Cerioni, Luca. 2005. "Harmful tax competition revisited: why not a purely legal perspective under EC law". European Taxation (7): 267-281.

Cooper, Graeme S. 1997. "Conflicts, challenges and choices - the rule of law and anti-avoidance rules". In Tax Avoidance and the Rule of Law, edited by Graeme S. Cooper, 13-50. Amsterdam, Netherlands: IBFD.

Cornielje, Simon \& Ivan Bondarev. 2015. "Scanning the Scope of Skandia". International VAT Monitor (1/2): 17-21.

Dekov, Erik. 1995. "Moms og lønsumsafgift i koncerner - Med kravet om 100\% koncernejerskab går Danmark længere end EU”. Revision \& Regnskabsvæsen 64 (9): 56-57.

Doesum, Ad van, Herman van Kesteren \& Gert-Jan van Norden. 2016. Fundamentals of EU VAT Law. Alphen aan den Rijn, Netherlands: Kluwer Law International B.V.

Douma, Sjoerd \& Caroline Naumburg. 2006. “Marks \& Spencer: Are National Tax Systems Éclairé?”. European Taxation (9): 431-442.

Dyrnes, Cecilie Aasprong. 2015a. "Virkningene av fellesregistrering for merverdiavgift". In Aktuell merverdiavgiftsrett, edited by Ole Gjems-Onstad \& Cecilie Aasprong Dyrnes, 123-139. Oslo, Norge: Gyldendal Juridisk.

Dyrnes, Cecilie Aasprong. 2015b. “Utvalgte dommer i merverdiavgift fra EU-domstolen". In Aktuell merverdiavgiftsrett, edited by Ole Gjems-Onstad \& Cecilie Aasprong Dyrnes, 192-219. Oslo, Norge: Gyldendal Juridisk.

Ehrke-Rabel, Tina. 2015. "VAT grouping: the relevance of the territorial restriction of Article 11 of the VAT Directive". World Journal of VAT/GST Law 1 (1): 61-79.

Ek, Mikael. 2013. "De svenska mervärdesskattegruppsreglerna - i linje med EU-rätten?”. Skattenytt: 631-635.
Elgaard, Karina Kim Egholm. 2016a. Interaktionen mellem momsretten og indkomstskatteretten. Copenhagen, Denmark: Jurist- og $\emptyset$ konomforbundets Forlag.

Elgaard, Karina Kim Egholm. 2016b. "The impact of the Charter of Fundamental Rights of the European Union on VAT law”. World Journal of VAT/GST Law: 1-29.

Engers, Søren. 1996. “Moms - trafikselskab - leasing”. Tidsskrift for Skatter og afgifter: 406-411.

Eskildsen, Casper Bjerregaard. 2011. "Fællesregistrering - en analyse af momslovens § 47, stk. 4”. Skat Udland: 62.

Feria, Rita de la. 2011. "Introduction: Introducing the Principle of Prohibition of Abuse of Law". In Prohibition of Abuse of Law, A New General Principle of EU Law?, edited by Rita de la Feria \& Stefan Vogenauer, xvi-xxvi. Oxford and Portland, Oregon, USA: Hart Publishing.

Fjermeros, Morten. 2014. "Bevisvurdering og omgåelsesnorm”. Revisjon og regnskap (6): 45-54.

Folkvord, Benn. 2015. "Hva er igjen av den ulovfestede omgåelsesnormen etter Rt 2014 s. 227 'Tangen'?”. Skatterett 34 (2): 150-164.

Folkvord, Benn. 2016. "Lovfestet omgåelsesnorm - Forslag som ikke vet hvor det vil”. Skatterett 35 (2): 177-185.

Gerson, Anna. 2011. "The Negative Harmonization Process of Losses in Foreign EU Subsidiaries: The Swedish Case". EC Tax Review (6): 273-282.

Gjems-Onstad, Ole. 1998. "Rettskilder i skatteretten - et norsk perspektiv". Skattenytt (1-2): 2.

Gjems-Onstad, Ole. 2009. “Omgåelse og merverdiavgift”. Skatterett 28 (2): 115-142.

Gjems-Onstad, Ole. 2012. "Merverdiavgift og inntektsskatt - momenter til en sammenligning med særlig vekt på internasjonale forhold". In Praktisk merverdiavgiftsrett, edited by Ole GjemsOnstad, Cecilie Aasprong Dyrnes \& Tor S. Kildal, 201-215. Oslo, Norge: Gyldendal Juridisk.

Gjems-Onstad, Ole. 2016. “Uforutsigbar omgåelsesnorm”. Skatterett 35 (2): 156-170.

Gjems-Onstad, Ole \& Tor S. Kildal. 2013. Lærebok i merverdiavgift (4th edition). Oslo, Norge: Gyldendal Juridisk.

Gjems-Onstad, Ole et al. 2016. MVA-kommentaren (5th edition). Oslo, Norge: Gyldendal Juridisk.

Hansen, Benny Hjortkær. 1994. “Nogle momsmæssige betragtninger - i lyset af L 124 om revision af momsloven". Tidsskrift for Skatter og afgifter: 194-195.

Hansen, Benny Hjortkær \& Erik Dekov. 1995. "Nye afgørelser om moms". SR-skat: 351-354.

Harris, Peter. 2013. Corporate Tax Law : Structure, Policy and Practice. Cambridge, UK: Cambridge University Press.

Hefner, Jan. 1998. "Gruppregistrering i mervärdesskattesystemet”. Svensk Skattetidning (6-7): 551.

Hellner, Jan. 1994. Rättsteori, En introduktion (2 ${ }^{\text {nd }}$ edition). Stockholm, Sweden: Juristförlaget.

Henkow, Oskar. 2008. Financial Activities in European VAT. Alphen aan den Rijn, Netherlands: Kluwer Law International.

Henkow, Oskar. 2009. “Några iakttagelser rörande hanteringen av intäkter från finansiella aktiviteter vid mervärdesbeskattningen och inkomstbeskattningen”. Skattenytt: 139-149.

Holmlund, Mats \& Pär Sundberg. 2014. "Slopad gruppregistrering til mervärdesskatt?”. Svensk Skattetidning (5): 368.

Ihlebæk, Susanne Åsheim. 2011. "Merverdiavgiftsbehandlingen ved innførsel og utførsel av tjenester - er reglene om de fjernleverbare tjenester i harmoni med EU-reglene?". Skatterett 30 (4): 333-344. 
Jensen, Dennis Ramsdahl. 2011. "Realitets- og misbrugsbetragtninger i EU-skatteretten". In Festskrift til Jan Pedersen, edited by Malene Kerzel, 171-191. Copenhagen, Denmark: Jurist- og $\emptyset$ konomforbundets Forlag.

Jensen, Dennis Ramsdahl. 2014. "Subjektafgrænsning i det fælleseuropæiske momssystem - En trist rejse fra FCE Bank til Crédit Lyonnais". Nordic Tax Journal (1): 102-122.

Jensen, Dennis Ramsdahl. 2015. "Misbrugsprincippet - djævlen i skyggerne". In Den evige udfordring - omgåelse og misbrug $i$ skatteretten, edited by Jakob Bundgaard, Dennis Ramsdahl Jensen \& Niels Winther-Sørensen, 53-79. Copenhagen, Denmark: Ex Tuto Publishing A/S.

Jensen, Martin. 2009. “Manglen på grænseoverskridende fællesregistrering i momsloven - $\mathrm{i}$ et nationalt og EU-retligt perspektiv". Skat Udland: 280.

Karlsson, Tomas \& Royne Schiess. 2013. "EU-domstolen om de svenska momsgruppsreglerna, dom i mål C-480/10, den 25 april 2013”. Svensk Skattetidning (5): 449-453.

Kildal, Tor S. 2008a. “Nytt avgiftsdirektiv - viktig for norske næringsdrivende". Revisjon og Regnskap (5): 67-70.

Kildal, Tor S. 2008b. "Skatt og EØS - implementering av EØSforpliktelser i norsk rett”. Praktisk Økonomi \& Finans 24 (1): 77-83.

Killengreen, John, Trond Larsen \& Frode Heggdal Larsen. 2000a. “Gjennomskæring på avgiftsrettens område Del 1". Revisjon og Regnskap (1): 26-34.

Killengreen, John, Trond Larsen \& Frode Heggdal Larsen. 2000b. “Gjennomskæring på avgiftsrettens område Del 2". Revisjon og Regnskap (2): 60-65.

Kirketerp, Claus. 2001. “Momsfradragsretten i bevægelse”. Revision \& Regnskabsvæsen (2): 6.

Kofler, Georg \& Michael Tumpel. 2009. “'Abuse' in Direct and Indirect Community Tax Law: A Convergence of Standards?". In Value Added Tax and Direct Taxation, Similarities and Differences, edited by Michael Lang, Peter Melz \& Eleonor Kristoffersson. Amsterdam, Netherlands: IBFD.

Kolozs, Borbála. 2009. "Neutrality in VAT”. In Value Added Tax and Direct Taxation, Similarities and Differences, edited by Michael Lang, Peter Melz \& Eleonor Kristoffersson. Amsterdam, Netherlands: IBFD.

Kristoffersson, Eleonor. 2009. "Groups of Companies and IntraCompany Dealings - A Comparison between Income Tax and Value Added Tax". In Value Added Tax and Direct Taxation, Similarities and Differences, edited by Michael Lang, Peter Melz \& Eleonor Kristoffersson. Amsterdam, Netherlands: IBFD.

Kristoffersson, Eleonor. 2010. “Något om komparativ metod i skatterätten”. Svensk Skattetidning (3): 278.

Kristoffersson, Eleonor. 2013a. "Tax fraud, tax abuse and the right to deduct input VAT in Sweden". World Journal of VAT/GST Law 2 (3): 261-267.

Kristoffersson, Eleonor. 2013b. "Skattebedrägerier, förfarandemissbruk och avdragsrätt för ingående mervärdesskatt”. Skattenytt: 598-612.

Kristoffersson, Eleonor. 2014. "Cross-border supplies and VAT groups: the Skandia America Corp judgment”. World Journal of VAT/GST Law 3 (3): 219-223.

Kristoffersson, Eleonor. 2015: "Tillhandahållande av tjänster inom gränsöverskridande mervärdesskattegrupper”. Svensk Skattetidning (1): 67-74.

Kristoffersson, Eleonor. 2016. "Comparative studies of national law in the EU harmonized VAT”. Nordic Tax Journal (1): 29-40.
Lampreave, Patricia. 2011. "Fiscal Competitiveness versus Harmful Tax Competition in the European Union”. Bulletin for International Taxation 65 (6): 17-37.

Larsen, Frode Heggdal. 2011. “Omgåelsesnorm på avgiftsrettens område”. Revisjon og Regnskap (5): 55-58

Lodin, Sven-Olof et al. 2015. Inkomstskatt Del 2 - en läro- och handbok i skatterätt (15th edition). Lund, Sweden: Studentlitteratur AB.

Lundeland, Kåre. 2009. "Den ulovfestede gjennomskæringsregel $\mathrm{i}$ skatte- og avgiftsretten”. Skatterett 28 (1): 56-65.

Løvass, Ivar. 2007. “Tilsidesettelse på merverdiavgiftslovens område (med paralleller til skatteretten)”. Skatterett 26 (1): 37-53.

Magnusson, Håkan. 1998. "Gruppregistrering till mervärdesskatt”. Skattenytt: 767-777.

Massin, Ivan \& Kenneth Vyncke. 2009. "EC Communication on VAT Grouping: An Attempt to Harmonize or to Restrict the Use of Group Registration?”. International VAT Monitor (11/12): 454-461.

Merkx, Madeleine. 2016. "VAT and Holding Companies: Position Finally Clear?”. EC Tax Review (1): 49-53.

Mikelsen, Anders. 2016. "En generell omgåelsesnorm for skatt og merverdiavgift - noen kritiske bemerkninger til NOU 2016:5". Skatterett 35 (2): 171-176.

Millar, Rebecca et al. 2016. "VAT Implications of Outsourcing". Bulletin for International Taxation (7): 387-398.

Monès, Sébastien de et al. 2010. "Abuse of Tax Law across Europe". EC Tax Review (2): 85-96.

Nedimovic, Biljana and Bjørn Christian Lilletvedt Tovsen. 2014. "EUdom kan give nye MVA-regler”. Revisjon og regnskap (7): 71-73.

Norden, Gert-Jan van. 2016. "State of Play in Respect of the Skandia America Corporation Case”. EC Tax Review (4): 211-220.

Nordquist, Richard. 2011. "Förarbetenas rättskällestatus - ett historiskt perspektiv”. Juridisk Publikation (1): 141-147.

Norli, Geir Tollak Bjørndal. 2016. Mottakerbegrepet for fjernleverbare tjenester - del 1. Skatterett 34 (1): 72-114.

Olsen, Kim Krüger and Eivind Bell Saxegaard. 2009. “Momsunntaket for finansielle tjenester og endret EF-direktiv". Revisjon og regnskap (2): 62-65.

Papis, Marta. 2014. “The Principle of Neutrality in EU VAT”. In Principles of Law: Function, Status and Impact in EU Tax Law, edited by Cécile Brokelind, 365-390. Amsterdam, Netherlands: IBFD.

Parolini, Andrea. 2008. "European VAT and Groups of Companies". In International and EC Tax Aspects of Groups of Companies, edited by Guglielmo Maisto. Amsterdam, Netherlands: IBFD.

Parolini, Andrea. 2009. "Cross-Border Group Taxation Regimes: VAT/GST v. Direct Taxation". In Value Added Tax and Direct Taxation, Similarities and Differences, edited by Michael Lang, Peter Melz \& Eleonor Kristoffersson. Amsterdam, Netherlands: IBFD.

Parolini, Andrea et al. 2011. "VAT and Group Companies". Bulletin for International Taxation (6): 349-362.

Peczenik, Aleksander. 1998. "Skatterättens föränderliga rättskälleprinciper”. Skattenytt 9: 536-540.

Pfeiffer, Sebastian. 2015a. VAT Grouping from a European Perspective. Amsterdam, Netherlands: IBFD.

Pfeiffer, Sebastian. 2015b. "Current questions of EU VAT grouping”. World Journal of VAT/GST Law: 1-15.

Piantavigna, Paolo. 2011. "Tax Abuse in European Union Law: A Theory”. EC Tax Review (3): 134-147.

Pistone, Pasquale \& Rita Szudoczky. 2016. "Chapter 2 - The Coordination of Tax Policies in the EU". In Introduction to European Tax Law: Direct Taxation, $4^{\text {th }}$ edition, edited by Michael Lang et al., 2751. Wien, Austria: Linde. 
Rendahl, Pernilla. 2016. "The Functionality of VAT: A Swedish Perspective". Intertax 44 (4): 341-346.

Ridsdale, Michael. 2005. "Abuse of rights, fiscal neutrality and VAT". EC Tax Review (2): 82-94.

Schön, Wolfgang. 2002. "Tax Competition in Europe - The National Perspective”. European Taxation (12): 490-500.

Selting, Leonie. 2010. “Mervärdesskattegrupper och Ampliscientifica - nya guidelines från Kommissionen. Skattenytt: 537-551.

Skogrand, Thor Inge. 2007. "Fellesregistrering etter merverdiavgiftsloven: Endret fortolkning av selskapsbegrepet”. Revisjon og regnskap (6): 59-61.

Soares, Claudia Dias \& Afonso Arnaldo. 2015. "VAT Grouping Schemes - Standpoint”. International VAT Monitor (3/4): 86-93.

Ståhl, Kristina. 2000. "The Application of the Treaty Nondiscrimination Principle in Sweden”. Intertax 28 (5): 195-199.

Swinkels, Joep. 2005. “Combating VAT Avoidance”. International VAT Monitor (7/8): 235-246.

Swinkels, Joep. 2010. "The Phenomenon of VAT Groups under EU Law and Their VAT-Saving Aspects.” International VAT Monitor (1): 36 42.

Swinkels, Joep J.P. 2011. “Abuse of EU VAT Law”. International VAT Monitor (4): 223-229.

Terra, Ben \& Julie Kajus. 2014. A Guide to the European VAT Directives, Volume 1. IBFD.

Tvarnøe, Christina D. \& Ruth Nielsen. 2014. Retskilder \& retsteorier $4^{\text {th }}$ edition. Copenhagen, Denmark: Jurist- og Økonomforbundets Forlag.
Vanistendael, Frans J. 2001. "Janus with Two Faces, or the Many Faces of Taxation”. In Liber Amicorum Sven-Olof Lodin, edited by Krister Andersson, Peter Melz \& Christer Silfverberg, 21-39. Stockholm, Sweden: Kluwer Law International.

Vyncke, Kenneth. 2007. "VAT Grouping in the European Union: Purposes, Possibilities and Limitations". International VAT Monitor (7/8): 250-261.

Vyncke, Kenneth. 2009. "EU VAT Grouping from a Comparative Tax Law Perspective”. EC Tax Review (6): 299-309.

Westberg, Björn. 1994. Nordisk mervärdesskatterätt - behandlingen av utländska företag, varor eller tjänster inom ramen för nationella lagar. Stockholm, Sweden: Juristförlaget.

Wiig, Oddgeir. 2014. "Fradrag for inngående merverdiavgift $i$ fellesregistrerte enheter”. Skatterett 33 (1): 43-62.

Wiman, Bertil. 1991. Koncernbeskattning. Uppsala, Sweden: Iustus.

Wiman, Bertil. 2002. Beskattning av företagsgrupper. Stockholm, Sweden: Norstedts Juridik AB.

Wroldsen, Markus D. 2014. "Sammensatte ytelser og merverdiavgift”. Revisjon og Regnskap (6): 55-62.

Zimmer, Frederik. 2007. "Hva er vurderingstemaet i omgåelsessaker?”. Skatterett 26 (1): 2-13.

Zimmer, Frederik. 2014. Lærebok $i$ skatterett, $7^{\text {th }}$ edition. Oslo, Norway: Universitetsforlaget.

Aasen, Lars \& Trine A. Lorentzen. 2008a. "Konsernbidrag og skatt”. Revisjon og regnskap 78 (3): 49-53.

Aasen, Lars \& Trine A. Lorentzen. 2008b. “Konsernbidrag og skatt”. Revisjon og regnskap 78 (4): 42-50. 